\title{
JURIES AND JUSTICE: ARE MALPRACTICE AND OTHER PERSONAL INJURIES CREATED EQUAL?
}

\author{
Randall R. Bovbjerg," Frank A. Sloan,** \\ Avi Dor, *** and Chee Ruey Hsieh****
}

\section{Introduction: The Central Role of Juries}

Liability for personal injury has become big business. ${ }^{1}$ According to some, it is also a rotten business. ${ }^{2}$ At the head of the long line of complainants stands the medical profession, objecting that doctors and hospitals are too often unfairly singled out to pay excessive damages. ${ }^{3}$

By far the most common type of liability case is the automobile tort. ${ }^{4}$ Thus, automobile cases (of course omitting claims for property damage) are the natural benchmark against which to compare other types of personal

Copyright $(\mathcal{C} 1991$ by Law and Contemporary Problems

* Senior Research Associate, The Urban Institute, Washington, D.C.

** Centennial Professor of Economics and Director, Health Policy Center, Institute for Public Policy Studies, Vanderbilt University.

*** Research Fellow, Center for General Health Services Intramural Research, Agency for Health Care Policy and Research; formerly Research Associate, The Urban Institute, Washington, D.C.

**** Economist, Institute of Economics, Academia Sinica, Taipai, Republic of China; formerly Research Assistant, Health Policy Center, Institute for Public Policy Studies, Vanderbilt University.

This article was supported by grant number IRO1 HS05683 from the National Center for Health Services Research (now reorganized as the Agency for Health Care Policy and Research). The authors gratefully acknowledge the many contributions of Penny B. Githens, who supervised data base construction; Sharon Stanley, who keypunched innumerable jury verdict abstracts; Daniel S. Gaylin, who produced the graphics; and numerous jury verdict coders. We also thank Mark $A$. Peterson and Deborah R. Hensler of RAND, who shared their jury verdict coding system and much of RAND's jury verdict data. The authors remain solely responsible for the contents of this article.

1. Robert W. Sturgis, Tort Cost Trends: An International Perspective 12 (Tillinghast, a Towers Perrin Company, 1989) (over 2.5\% of GNP in the United States for 1987 compared to about $0.5 \%$ elsewhere in the developed world); James S. Kakalik \& Nicholas M. Pace, Costs and Compensation Paid in Tort Litigation vi and vii, at 74, Fig 7.2 (RAND, 1986) (R-339I-ICJ) (total cost of tort lawsuits terminated in 1985 between $\$ 29$ and $\$ 36$ billion) ("Costs and Compensation").

2. See, for example, Peter W. Huber, Liability: The Legal Revolution and Its Consequences 4 (Basic Books, 1988) (very critical of annual liability "tax" of at least $\$ 80$ billion, perhaps as high as $\$ 300$ billion); Jeffrey O'Connell \& $\mathrm{C}$. Brian Kelly, The Blame Game: Injuries, Insurance, and Injustice (Lexington Books, 1987).

3. See, for example, Am Med Ass'n, A Proposed Alternative to the Civil Justice System for Resolving Medical Liability Dispules: A Fault-Based, Administrative System (January 1988) ("A Proposed Alternative"); Am Med Ass'n, Professional Liability' in the '80s, reports 1-3 (October 1984, November 1984, March 1985).

4. See, for example, Kakalik \& Pace, Costs and Compensation at 14, Table 2.4 (cited in note 1) (estimated 478,000 automobile cases or $55 \%$ of state court tort filings, and 7,000 or $17 \%$ in federal courts, which attract higher-value cases). 
injury claims. Automotive, medical, and the many other types of litigable injuries are all assessed by essentially the same system of tort law and liability insurance. ${ }^{5}$ The core of this entire enterprise is the hallowed American institution of the civil jury. Juries resolve only a small share of claims, but their decisions greatly influence the far more numerous settlement negotiations among plaintiffs, defense counsel, and insurance claims adjusters. ${ }^{6}$

A major complaint of well-insured defendants, especially physicians, is that juries are biased against defendants, especially those with "deep pockets."7 This availability of funds allegedly encourages easier awards of higher damages for similar injuries and hence the bringing of less meritorious claims. These concerns find some empirical support in the work of analysts at RAND. ${ }^{8}$ On the other side of the issue stand the trial lawyers and some consumer advocates. ${ }^{9}$

The policy issue at stake is whether society should accept the system's current performance, further reform its operations, or replace the system altogether. An additional issue is whether any legal changes should apply to all types of personal injury or whether there are good reasons for singling out medical malpractice.

If true, the physicians' complaints of jury bias provide one justification for malpractice-specific reform, akin to almost all of the tort reforms enacted in the mid-1970s. ${ }^{10}$ The $1980 \mathrm{~s}^{\prime}$ reforms were more apt to be generic, that is, to cover all personal injury lawsuits or all torts, rather than only medical malpractice. ${ }^{11}$ Although organized medicine has joined in coalitions to

5. William Page Keeton, et al, Prosser and Keeton on Torts (West, 5th ed 1984) ("Prosser E̋ Keeton").

6. See, for example, Stephen Daniels \& Lori Andrews, The Shadow of the Law: Jury Decisions in Obstetrics and Gynecology Cases, in Victoria P. Rostow \& Roger J. Bulger, eds, 2 Medical Professional Liability and the Delivery of Obstetrical Care: An Interdisciplinary Review (Nat'l Acad Press, 1989) ("The Shadow of the Law"); H. Laurence Ross, Settled Out of Court: The Social Process of Insurance Claims Adjustment (Aldine, 2d ed 1980) ("Settled Out of Court"). See also discussion of settlement model below, at notes $20-37$.

7. See, for example, James K. Hammitt, Stephen J. Carroll \& Daniel A. Relles, Tort Standards and Jury Decisions, $14 \mathrm{~J}$ Legal Stud 75I, $754 \mathrm{n} 8$ (1985).

8. For example, Audrey Chin \& Mark A. Peterson, Deep Pockets, Empty Pockets: Who Wins in Cook County Jury Trials (RAND, 1985) (R-3249-ICJ); Mark A. Peterson, Compensation of Injuries: Civil Jury Verdicts in Cook County 35 (RAND, 1984) (R-3011-ICJ) (average malpractice or other "high stakes" injury receives jury verdict ten to thirteen times higher than average automobile injury, some four times higher controlling for the severity of injury and other factors) (cited by Am Med Ass'n, $A$ Proposed Alternative at 10 (cited in note 3); Hammitt, Carroll \& Relles, $14 \mathrm{~J}$ Legal Stud at 753.56 (cited in note 7)).

9. See, for example, Tony C. Dunningham \& Robin Lane, Malpractice-The Illusory Crisis, 54 Fla Bar J 114 (1980); Thomas Goddard, The American Medical Association is Wrong-There is No Medical Malpractice Insurance Crisis (unpublished paper for the Public Affairs Dep't, Ass'n Trial Lawyers of America, issued 1985); The Need for Disciplinary Reform, Not Tort Reform (Public Citizens Health Res Group, 1985) (press release).

10. See, for example, Comment, An Analysis of State Legislative Responses to the Malpractice Crisis, 1975 Duke LJ 1417; Kenneth S. Abraham, Medical Malpractice Reform: A Preliminary Analysis, 36 Md L Rev 489 (1977).

11. Randall R. Bovbjerg, Legislation on Medical Malpractice: Further Developments and a Preliminary Report Card, 22 UC Davis L Rev 499 (1989). 
promote generic tort reform, since the late 1980s the American Medical Association ("AMA") and medical specialty societies have pressed to treat malpractice cases separately. Their plan would remove medical liability from the civil justice system, for resolution under modified rules through an administrative process. ${ }^{12}$ How, if at all, to effect reform still ranks high on both state and federal agendas, despite the recent return to normalcy in liability insurance markets.

This article documents how jury verdicts for malpractice and other "deep pocket" personal injury defendants (products liability and government cases) compare with ordinary defendants (automobile torts) and analyzes possible explanations for observed differences. The dynamics of litigation and the probability of winning are also addressed, as well as change over time. The data come from jury verdicts reported in five different states, combining data previously computerized by RAND researchers with similarly compiled information by the authors (see Appendix 1). We assess jury verdicts in these selected types of cases as a lens to focus on the larger issues of jury performance and extra-judicial reform.

The data show that juries do better than their critics allege, although costs of litigation are very high. Most of the observed variation in valuation of injury is explained by logical factors such as severity of injury and age of claimant. Other observed factors equal, however, malpractice cases do receive higher awards. Yet the difference does not seem to result from acrossthe-board jury bias or antipathy to doctors, as physicians contend, for most malpractice "awards" are zero, quite unlike most automobile awards. Nor does the lawyers' perspective seem supportable, that malpractice injuries are objectively worse in ways not captured by current data. Rather, a more persuasive hypothesis to explain the variation in valuation of injury is that plaintiffs' lawyers disproportionately select for trial cases of uncertain liability where subjective damages are higher (for example, nonpecuniary loss by sympathetic claimant). The policy conclusion is that problems in damage valuations need to be addressed across the board, not for malpractice cases alone. Problems in jury assessments of medical negligence or causation may justify malpractice-specific reform, but the case is not strong based on errors in damages.

\section{II}

From Injury to Jury: Understanding How Cases ProceEd TO Trial

Fully understanding jury verdicts calls for understanding how claimants and lawyers select cases for trial. Juries see only a small proportion of all malpractice and other disputes. Though these selected cases are not typical, their results greatly influence settlements. This article assumes the following

12. Am Med Ass'n, A Proposed Altermative (cited in note 3). 
model of dispute resolution and legal behavior, from the underlying injury to jury verdict, in analyzing juries' valuations of different types of lawsuits.

\section{A. From Injury to Claim or Lawsuit}

It is axiomatic that every personal injury lawsuit begins with an injury, real or imagined. So dispute resolution starts with a pool of injuries from various causes, for example, automobile accidents, slips and falls on public premises, defective products, or medical negligence. The size of this pool can only be estimated. ${ }^{13}$ There is no shortage of suggestions, often from high-ranking sources, ${ }^{14}$ that America is a "litigious society." Yet most incidents of malpractice, at least, never become claims or lawsuits. ${ }^{15}$ How injured parties decide whether to pursue a claim or lawsuit is not well understood, ${ }^{16}$ although states' legal regimes have been empirically shown to influence the rate of malpractice claims, ${ }^{17}$ and economic, social, and other factors are surely

13. Data on injury (as opposed to claims) come from such sources as statutorily required reporting of motor vehicle accidents, hospital emergency room reporting, and special surveys. Two publisheci studies have estimated the extent of malpractice injury, at least for hospital incidents, which give rise to most claims, at about $1 \%$ of hospitalizations. Don Harper Mills, John S. Boyden, Jr. \& David S. Rubsamen, Report on the Medical Insurance Feasibility Study 97-101 (Sutter, 1977) (sponsored jointly by the California Medical and Hospital Associations) (rate of $0.8 \%$ estimated for California hospitals in 1974), summarized in Don Harper Mills, Medical Insurance Feasibility Study: $A$ Technical Summary, 128 West J Med 360 (1978); Harvard Medical Practice Study, Patients, Doctors, and Lawyers: Medical Injury, Malpractice Litigation, and Patient Compensation in New York 3, 6-1 (February 1990) (1.0\% rate for New York hospitals in 1984) ("New York Study"). Over 30 million hospitalizations occur nationally each year, US Dep't Commerce, 1989 Statistical Abstract of the United States Table 161, so that some 300,000 negligent hospital injuries can be expected.

14. See, for example, Warren E. Burger, Isn't There a Better Way?, 68 Am Bar Ass'n J 274 (1982); Tort Policy Working Group, Report of the Tort Policy Working Group on the Causes, Extent and Policy Implications of the Current Crisis in Insurance Availability (US Dep't Justice, 1986).

15. Negligent hospital injuries outnumber claims by a factor of eight or ten to one, according to data from the two hospital-injury studies. Don Harper Mills, Comments on Where We Stand and What We Know, presented at the Urban Institute conference, Medical Malpractice: Can the Private Sector Find Relief, Washington, D.C. (February 21, 1985) (10:1 ratio for California in 1974); Patricia M. Danzon, Medical Malpractice: Theory, Evidence, and Public Policy 20-25 (Harvard U Press, 1985) (estimating 5:1 ratio for California in 1984 based on growth in claims since 1974) ("Medical Malpractice"); New York Study at 7-24 to 7-41 (cited in note 13) (8:1 ratio for New York in 1984).

16. The classic case-study analysis, Roger Bryant Hunting \& Gloria S. Neuwirth, Who Sues in New York City (Columbia U Press, 1962), considered automobile victims' losses, experience, attitudes, and background. Subsequent research, much of it in the law and society literature, focuses on demographics and other background concerns. For example, William L.F. Felsteiner, Richard L. Abel \& Austin Sarat, The Emergence and Transformation of Disputes: Naming, Blaming, Claiming. . . 15 L \& Soc'y Rev 631, 640 (1980-81); Michele Hoyman \& Lamont Stallworth, Suit Filing by Women: An Empirical Analysis, 62 Notre Dame L Rev 6 (1986); Austin Sarat, Studying American Legal Culture: An Assessment of Survey Evidence, 11 L \& Soc'y Rev 427 (1977). There seems to have been little empirical examination of the role of first-party or social insurance coverage, which pays for most damages from injury. Alfred F. Conard, et al, Automobile Accident Costs and Payments: Studies in the Economics of Injury Reparation 17 (U Mich Press, 1964). On the paucity of malpractice evidence, see generally Stephen Zuckerman, Christopher F. Koller \& Randall R. Bovbjerg, Information on Malpractice: A Revieu of Empirical Research on Major Policy Issues, 49 L \& Contemp Probs 85, 94-97 (Spring 1986); Marlynn L. May \& Laura DeMarco, Patients and Doctors Disputing: Patients ' Complaints and What They Do About Them, 24 L \& Soc'y Rev 105 (1990).

17. Patricia M. Danzon, The Frequency and Severity of Medical Malpractice Cases, $27 \mathrm{~J}$ L \& Econ 115 (1984) (analyzing inter alia how many "pro-plaintiff" common law developments had occurred in each jurisdiction). 
involved as well. ${ }^{18}$ Victims of automobile accidents, for example, appear more likely than victims of malpractice to consult a lawyer. ${ }^{19}$

\section{B. Lawyers' Decisionmaking: Settlement versus Litigation to Trial}

Whatever motivates injured parties, it is also axiomatic that plaintiffs' attorneys greatly influence what litigation is filed, settled, and tried. Claimants need lawyers, and lawyers screen cases for legal merit and economic return. One survey found that, nationally, all lawyers refuse seven of eight malpractice cases brought to them for evaluation. ${ }^{20}$ Plaintiffs' lawyers' contingent fees make them not merely disinterested purveyors of expert legal services but also "investors" in their clients' causes, so they are well motivated to consider expected returns. Lawyers' decisionmaking on behalf of their clients has been the subject of much legal writing as well as social science analysis, discussed next. ${ }^{21}$

The standard social science analysis models resolution of each case as a bargaining game: the two competing, self-interested sides are risk neutral and consider the expected economic impact on them at every stage. ${ }^{22}$ Claimants and their lawyers ${ }^{23}$ maximize their net return (settlement or award less expenses), while defendants, insurers, and their lawyers minimize their total

18. Donald N. DeWees, Michael J. Trebilcock \& Peter C. Coyte, The Medical Malpractice Crisis: A Comparative Empirical Perspective, 54 L \& Contemp Probs 217 (Winter 1991).

19. See All-Industry Research Advisory Council, Attorney Involvement in Auto Injury Claims 9-11 (1988) $(95 \%$ of families with automobile personal injury in 1986 filed automobile insurance claims, including no-fault; $35 \%$ hired attorneys, a good indicator of a tort claim) ("Attorney Involvement"). In contrast, one malpractice study of patients' self-reported "negative medical care experiences" found that fully $42 \%$ of respondents' families had had at least one such experience, almost $17 \%$ within the last year. Of these, $63 \%$ sought further medical care as a result, but only $8 \%$ sought legal advicelisting both pecuniary and non-pecuniary motivations in equal measure. Active consideration of seeking legal advice was most strongly associated with measures of the amount of damage or injury. Mark A. Peterson, Consumers 'Knowledge of and Attitudes toward Medical Malpractice, in Dep't of Health, Educ. \& Welfare, Report of the Secretary's Commission on Medical Malpractice Appendix, 658 (1973) (OS 73-89) ("Consumer's Knowledge").

20. Lawyers with a significant malpractice case load, however, accepted a much higher share (in part, one supposes, because of prior screening of some cases by referring attorneys). The main reason for rejection was "no perceived liability." Stephen Dietz, C. Bruce Baird \& Lawrence Berul, The Medical Malpractice Legal System, in Dep't of Health, Educ. \& Welfare, Report of the Secretary's Commission on Medical Malpractice Appendix, 87, 97-100 (1973) (OS 73-89).

21. See, for example, Melvin W. Reder, Contingent Fees in Litigation with Special Reference to Medical Malpractice, in Simon Rottenberg, ed, The Economics of Medical Malpractice 211 (Am Enterprise Inst, 1978); see generally Marc Galanter, Why the Haves Come Out Ahead: Speculations on the Limits of Legal Change, 9 L \& Soc'y Rev 95 (1974); Patricia M. Danzon, Contingent Fees for Personal Injury Litigation, 14 Bell J Econ 213 (Spring 1983).

22. For a review of the literature, see Robert D. Cooter \& Daniel L. Rubinfeld. Economic Analysis of Legal Disputes and Their Resolution, $27 \mathrm{~J}$ Econ Lit 1067 (1989). Traditional applications of the model. however, often considered the alternatives "settle" versus "trial" only at one decision point, whether to settle or go to trial. A newer approach analogizes a legal claim to an "option." which can be "sold" at any time and whose value changes as new information becomes available. This is more consistent with the legal reality of continuous decisionmaking at every stage. See Bradford Cornell, The Incentive to Sue: An Option-Pricing Approach, $19 \mathrm{~J}$ Legal Stud 173-87 (1990).

23. Lawyers are assumed to act in their clients' interests. This assumption eliminates principalagent conflicts. See Thomas D. Rowe, Jr., Predicting the Effects of Attorney Fee Shifting, 47 L \& Contemp Probs 139 (Winter 1984). 
loss (settlement or award plus expenses). ${ }^{24}$ Lawyers (and insurers) estimate each plaintiff's probability of winning and, if won, the probable level of damages. Estimates are based on knowledge of the applicable legal rules of liability and damages, investigation of the circumstances and nature of injury (for example, extent of wage and medical losses, residual disability, pain and suffering), and informed judgment about likely jury behavior. The model's assumptions are intuitively plausible and have served a number of formal analyses.

Using these and other simplifying assumptions, it follows that claims will be settled whenever the difference between the two sides' respective valuations of the case (perceived likelihood of liability times likely damages) is less than the (normally considerable ${ }^{25}$ ) expense of pursuing the case to a legal conclusion (jury verdict, potentially followed by judicial appeal). Otherwise stated, the defendant's maximum offer at any time is his then-expected value of verdict plus marginal litigation expense, whereas the plaintiff's minimum demand, or asking price, is her expected value less marginal litigation expense. The precise amount of the settlement between the two sides valuations is determined by the parties' relative bargaining power, which probably varies with legal talent and experience, resources available to finance litigation, and other factors. ${ }^{26}$ The standard model may be altered by assuming risk aversion ${ }^{27}$ or asymmetric information. For instance, on the defense side, manufacturers or physicians probably know more about the potential for proving negligence than do claimants or their lawyers. ${ }^{28}$ On the plaintiff's side, claimants probably know most about their own injuries. Of course, the legal process of pretrial discovery is meant to minimize informational imbalances, traditionally on the rationale of avoiding surprise at trial. Economic externalities (for example, "spillover" effects of one settlement on future $\operatorname{cases}^{29}$ ) or non-pecuniary motives (for example, a plaintiff's personal vengeance or a defendant's concern about reputation) can also complicate the model. Strategic behavior may also occur, as where "nuisance suits" are brought solely to force a settlement. ${ }^{30}$

24. The model has been developed over time. Leading presentations include William $\mathbf{M}$. Landes, An Economic Analysis of the Courts, $14 \mathrm{~J}$ L \& Econ 61 (1971); John P. Gould, The Economics of Legal Conflicts, $2 \mathrm{~J}$ Legal Stud 279 (1973); Richard A. Posner, Economic Analysis of Law 434-53 (Little. Brown, 2d ed 1977); and Steven Shavell, Suit, Settlement, and Trial: A Theoretical Analysis under Alternative Methods for the Allocation of Legal Costs, $11 \mathrm{~J}$ Legal Stud 55 (1982). See also note 22.

25. For the only known published calculation of the marginal expense of going to trial, see Thomas B. Metzloff, Resolving Malpractice Disputes: Imaging the Jury's Shadow, 54 L \& Contemp Probs 43, 56-59 (Winter 1991).

26. See W. Kip Viscusi, The Determinants of the Disposition of Product Liability Claims and Compensation for Bodily Injury, 15 J Legal Stud 321 (1986). See generally sources cited in note 24.

27. For example, W. Kip Viscusi, Product Liability Litigation with Risk Aversion, $17 \mathrm{~J}$ Legal Stud 101 (1988).

28. See, for example, Patricia M. Danzon, Liability and Liability Insurance for Medical Malpractice, $4 \mathrm{~J}$ Health Econ 309, 312-14 (1985); Ivan P. L. P'ng, Litigation. Liability, and Incentives for Care, 34 J Pub Econ 61 (1987).

29. See, for example. Jeffrey M. Pertoff \& Daniel L. Rubinfeld, Settlement in Private Antitrust Litigation, in Lawrence J. White, ed, Private Antitnust Litigation 149 (MIT Press, 1988).

30. Lucian Arye Bebchuk, Suing Solely to Extract a Settlement Offer, 17 J Legal Stud 437 (1988). 
Several implications follow from the standard model: The more variable the two sides' expectations about jury performance, the less likely are settlements. The higher the marginal costs of continuing at law, the more likely are settlements. Asymmetry of information, whether due to inherent advantage or quality of investigation, increases the likelihood of continuing to trial. And under rather restrictive assumptions, the model predicts that trials should result in a 50-50 split in outcomes between plaintiffs' and defendants' victories. $^{31}$ The intuition underlying this prediction is that well-informed, well-represented, and risk-neutral parties will settle the "obvious" cases, ones where juries' fact finding and application of the law are relatively predictable by both sides. Only the "difficult," unpredictable cases can be expected to proceed to trial (absent such assumed-away factors as vengeance, nuisance suits, and concern about impact on later similar suits). Further, where twosided outcomes are very unpredictable, as in a coin toss, results should favor each side about equally. It is of course an empirical matter whether the actual process hews closely to the predictive model or results indeed come out 50$50 .{ }^{32}$

It may at first seem counterintuitive that so few, and so atypical, cases could guide settlements in the far larger number of normal cases. ${ }^{33}$ However, "marginal" transactions regularly set values applicable far beyond the marginal case. Stockbrokers can "make a market" by trading relatively few shares of a security, for instance. Real estate appraisals, whether for eminent domain proceedings, local tax assessment, or second mortgages, are greatly influenced by the relatively few properties that are actually sold in a recent period. ${ }^{34}$ Moreover, common sense similarly indicates that jury outcomes must influence parties' negotiations, for either side can "hold out" for a trial. There are also practical indications that parties care greatly about jury results;

31. George L. Priest \& Benjamin Klein, The Selection of Disputes for Litigation, $13 \mathrm{~J}$ Legal Stud 1, 5 (1984)

32. See discussion below, at notes 75-83, of comparative win percentages adjusted for other influences. For other results, see sources cited in Metzloff, $54 \mathrm{~L}$ \& Contemp Probs at 64 \& n77 (cited in note 25).

33. Professor Metzloff, for one, seems skeptical of the guiding role of jury verdicts, especially with respect to determination of damages. Metzloff, $54 \mathrm{~L}$ \& Contemp Probs at 84-86, 88-92 (cited in note 25).

34. These observations do not mean that jury verdicts directly set the "going rate" in the same sense that stock market transactions do, for jury cases are atypical, not identical to settled ones. But responsible people often base valuations on information about non-identical "sales," as when the price received for a four-bedroom brick Colonial on the corner affects the perceived value of the three-bedroom clapboard Cape Cod down the block. In an analogy perhaps closer to home for a legal footnote, salaries set by a single Wall Street law firm for beginning associates can not only directly affect competing similar firms but also can indirectly influence many or most recruiting salaries thereafter. Similarly, prior jury results, along with prior settlement outcomes, indirectly affect settlements as the negotiating parties argue various analogies and distinctions from this imperfect "precedent." Jury verdicts do not represent the "gold standard" of valuation in the same way as does, say, an organized futures market in other types of contingent claims (for example, the right to buy or sell 1,000 ounces of precious metal next December 12th). Instead, in an economic sense, "fair market value" is set by free negotiation between willing plaintiff and willing defendant. Sometimes negotiation fails, however. Then, juries take over, so parties are constantly cognizant of what a jury might do. 
for example, lawyers subscribe to jury verdict reporters, ${ }^{35}$ insurers worry about cases of first impression and their likely effect on future claims, and insurers have been known to revalue claims reserves in response to observed shifts. $^{36}$ Descriptions of dispute resolution also note the influence of expected jury values on parties' negotiations about settlements. ${ }^{37}$

\section{Plaintiffs' Lawyers' Markets in Equilibrium}

Viewing a plaintiffs' lawyer's practice in its entirety as an "investor" in various contingent claims, we assume that the practice "invests" so as to maximize overall net returns on a "portfolio" of personal injury (and other) cases. The practice accepts or rejects personal injury cases of various types on their separate merits. ${ }^{38}$ We assume that contingent fees proportional to the amount awarded apply across types of cases and cover all legal costs (including the lawyer's own time), although we recognize that some separately billed expenses may be large in an unknown number of lawyer-client contracts. When the plaintiff wins a case, the plaintiff's lawyer earns a net return equal to the difference between the contingent fee and the cost of litigation (including the opportunity cost of their time). When the plaintiff loses, the lawyer incurs a financial loss equal to the cost of litigation. In the aggregate, the practice must meet the costs of lost cases out of the gains on the winners. So the level of return on won cases required to be competitive varies with the percentage of cases won as well as with the cost of that type of litigation.

Under this portfolio model, lawyers accept new cases of all types up to the point where the expected revenues of each case equal the expected litigation costs (with costs including a share of costs in losing cases). ${ }^{39}$ Competition from other lawyers and limited judicial oversight of fees are assumed to prevent the earning of above-normal returns. Cases whose probability of winning or value if won put their expected value below this point are rejected. In equilibrium, net returns must be equal across case types, for lawyers have taken all profitable cases of each type. Higher expected awards in a particular legal specialty or type of case thus necessarily imply higher costs.

35. See discussion of such reporters below in Appendix 1 , at notes 1 and 2 .

36. See generally Frank A. Sloan, Randall R. Bovbjerg \& Penny B. Githens, Insuring Medical Malpractice (Oxford U Press, 1991), especially chapter 6 on claims reserving.

37. See generally, for example, Ross, Settled out of Court (cited in note 6); see also Metzloff, 54 L \& Contemp Probs at 116-29 (cited in note 25) (quotation of insurance-file annotations).

38. Many trial lawyers litigate various types of personal injuries. Lawyers may specialize, of course, to build up expertise in complex types of cases where, for example, an understanding of engineering or medical practice is advantageous. Even with specialized individuals, however, a law office may take all types of cases, mixing particular knowledge and talents as appropriate. Interestingly, even though the two sides' need for expertise and legal talent are so similar, American trial lawyers, unlike barristers in Great Britain, normally do not "diversify" their litigation portfolios by taking both plaintiff and defense cases. One supposes that the explanation lies in differences of attitude and temperament as well as institutional defendants' and insurers' fears of what might be thereby disclosed that could hurt them in future cases.

39. See, for example, Melvin W. Reder, Medical Malpractice: An Economist 's View, 1976 Am Bar Found Res J 511,549 . 


\section{Behavior of Juries and Judges}

Legal actors are supposed to follow the rules of law dispassionately. So when disputes reach trial, the appropriate beginning "model" for their behavior is the basic law of torts and damages that juries and judges apply. ${ }^{40}$ Although rules of liability and evidence can vary by type of case, ${ }^{41}$ rules of damages are not variable. ${ }^{42}$ Thus, in legal theory, a plaintiff with the same pecuniary and nonpecuniary losses should get the same recovery regardless of whether she was hurt by a doctor, a driver, or a defective product. Unlike lawyers, who routinely settle cases on the basis of expected value (probability of liability times damages, adjusted for costs), jurors are instructed not to make such compromises, ${ }^{43}$ but rather to make winning plaintiffs "whole," with compensation to make their situation as good as if they had never been injured. ${ }^{44}$ Jurors are of course supposed to be disinterested (they can be excused from service otherwise) and to decide their case objectively, making decisions solely on the evidence presented. Although judges can correct jury errors in damages that were obviously due to prejudice or mistake, ${ }^{45}$ jury discretion and the predominance of general verdicts (without specific findings of fact) make any errors hard to detect.

How well do real juries and judges follow this model? In contrast to the logic of self-interested lawyers that has been rather thoroughly modelled, the performance of putatively disinterested legal actors-juries and judges-has not. ${ }^{46}$ Although there is some empirical evidence on their performance, most

40. In settlement negotiations, the opposing attorneys may not even refer to what a jury could be expected to do, rather asserting that their offer or demand is "objectively" correct. Compare Metzloff, $54 \mathrm{~L} \&$ Contemp Probs at 92-93 (cited in note 25). Apart from being an obvious negotiating ploy, another way to interpret this behavior is that lawyers normally expect judges and juries to do their legal duty and to do it dispassionately.

41. Thus, for example, negligence of an automobile driver is judged by the classic standard of the "reasonable person," and its application calls for common sense judgment by jurors ("Was driver X going too fast for the conditions?"). See, for example, Prosser $\mathcal{E}$ Keeton at $173-92$ (cited in note 5). The negligence of physicians, in contrast, must be shown as a departure from the customary practice of similar practitioners. For example, id; Allan $\mathrm{H}$. McCoid, The Care Required of Medical Practitioners, 12 Vand L. Rev 549 (1959). Thus, legal texts have to treat malpractice and products liability, for example, in separate sections, see, for example, Prosser E Keeton at 115-18, 185-93, 677724 (cited in note 5), and specialized legal treatises exist by subject areas, for example, David Louisell \& Harold Williams, Medical Malpractice (Mathew Bender, 1991).

42. Standardized texts thus provide a general treatment, for example, Prosser Eo Keeton (cited in note 5); Dan B. Dobbs, Handbook on the Law of Remedies (West, 1973); Charles Tilford McCormick, Handbook on the Law of Damages (West, 1935), and trial judges' charges to juries are also general. For one standard judicial charge to a jury, see $8 \mathrm{Am}$ Jur Pleadings E' Prac Forms Form 184 (Lawyer's Cooperative \& Bancroft-Whitney, rev ed 1982) ("Am Jur Pleadings").

43. See, for example, $8 \mathrm{Am}$ Jur Pleadings Form 137 (cited in note 42) ("In arriving at your verdict you must not make a compromise between the question of liability and the amount of the damages, if any."); see also McCormick, Handbook on the Law of Damages at $\S 16$ (cited in note 42).

44. For example, Restatement (Second) Torts $\$ 901$ (Am Law Inst, 1965). Where rules of "comparative negligence" apply, however, plaintiffs" awards are generally reduced by the percentage of their relative fault in the injury, under one of the several different versions of the doctrine. For example, Prosser $\dot{\sigma}^{\circ}$ Keeton at 468-80 (cited in note 5).

45. McCormick, Handbook on the Law of Damages, at $\S \S 16,19$ (cited in note 42). But judges are admonished to use these powers sparingly. Id.

46. Cooter \& Rubinfeld, $27 \mathrm{~J}$ Econ Lit at 1094 (cited in note 22). 
discussion occurs on a more qualitative plane. ${ }^{47}$ The classic case study, based on observing jury behavior, concluded in part that juries take their social obligations seriously and try hard to follow the legal rules. ${ }^{48}$ Similarly, one empirical analysis of the malpractice system concludes that "court awards are strongly influenced by the economic loss of the plaintiff and by the law of compensable damages." 49

Many argue, to the contrary, that jurors are often swayed by emotional and other legally extraneous factors. Some have gone so far as to label the process a "lottery." 50 The law certainly leaves considerable room for extraneous factors to influence jury valuation of cases, for the law of damages is incredibly vague and governed by ad hoc decisions. ${ }^{51}$ Jury instructions are almost wholly qualitative rather than quantitative, and the law lacks a good mechanism for achieving consistency across cases, even on judicial review. ${ }^{52}$ The law of damages has not even created any formal system for reporting of jury verdicts as it has for substantive law's reported appellate decisions. ${ }^{53}$

\section{E. Using the Model to Understand Jury Verdict Data}

Despite the attention to theoretical modelling of dispute resolution, there has been relatively little scholarly empirical analysis of jury awards. The lack of officially reported statistics may be partly responsible; primary data collection is a daunting exercise. Another possible explanation is a shortage of legal researchers with an empirical bent and of empirical researchers with a legal inclination. ${ }^{54}$ The leading recent exception to this generalization has been the work of researchers at RAND. They have analyzed privately compiled reporters of jury verdicts from two jurisdictions, suggesting, among other things, that juries' attitudes toward "deep pockets" explain patterns of

47. See, for example, Special Committee on the Tort Liability System, Towards a Jurisprudence of Injury; the Continuing Creation of a System of Substantive Justice in American Tort Law 8-15 to 8-32 (Am Bar Ass'n, 1984) (a report to the American Bar Association).

48. Harry Kalven, Jr., The Dignity of the Civil Jury, 50 Va L Rev 1055, 1062 (1964); compare Harry Kalven, Jr., \& Hans Zeisel, The American Jury (Little, Brown, 1966)

49. Danzon, Medical Malpractice at 222 (cited in note 15). Direct evidence on this point is provided in Frank A. Sloan \& Thomas J. Hoerger, Uncerlainty, Information and Resolution of Medical Malpractice Disputes, J Risk \& Uncertainty (forthcoming 1991).

50. For example, Jeffrey O'Connell, The Lawsuit Lottery: Only the Lawyers Win at 8-9 (The Free Press, 1979).

51. See Randall R. Bovbjerg, Frank A. Sloan \& James F. Blumstein, Valuing Life and Limb in Tort: Scheduling "Pain and Suffering," $83 \mathrm{Nw}$ U L Rev 908, 909-17 (1989).

52. See generally Walter J. Blum \& Harry Kalven, Jr., Public Lau Perspectives on a Private Law Problem (1965); Bovbjerg, Sloan \& Blumstein, $83 \mathrm{Nw}$ U L Rev at 909-19 (cited in note 51).

53. Bovbjerg, Sloan \& Blumstein, $83 \mathrm{Nw}$ U L Rev at 960-61 (cited in note 5l) (arguing for official reporting of damage awards and judgments); James F. Blumstein, Randall R. Bovbjerg \& Frank A. Sloan, Developing Better Tools for Assessing Damages for Personal Injuries: A Common Law of Damages and Insurance Contracts for Future Services, 8 Yale J Reg 171, 177-88 (Winter 1991) (arguing for development of "common law" of damages).

54. The paucity of systematic evidence about this important American institution may also partly be due to the desire to maintain a significant mystique. Plausibly, there may be a fear of piercing the veil, lest the legitimacy of an important "a-responsible" institution be compromised. On the importance of "a-responsible" institutions to make very difficult social decisions, see Guido Calabresi \& Philip Bobbit, Tragic Choices (Norton, 1978). 
awards. ${ }^{55} \mathrm{~A}$ few other researchers have also studied jury outcomes in similar fashion, emphasizing their importance in settlements as well. ${ }^{56}$

Using more jurisdictions for jury information, this article extends this analytic approach to investigate the deep-pocket and other hypotheses of jury behavior. It also adds other data bases to analyze differential jury valuations in light of lawyers' incentives to select equally "profitable" cases for trial. The specific hypotheses are examined next.

\section{III}

\section{The Doctors versus the Lawyers: Their Hypotheses and Their Evidence}

Controversy swirls about the accuracy and. fairness of jury verdicts. Physicians typically feel that the system overcompensates litigious patients. Attorneys often contend that malpractice cases are among the hardest to win and those cases going to trial necessarily involve larger losses than other types of cases. This section presents simple, descriptive information about jury verdicts in five jurisdictions, describes the prototypical competing explanations for the observed patterns, and explains the data used to analyze the patterns in more depth.

\section{A. Malpractice versus Other Jury Awards}

Figure 1 presents data on 1980-85 jury verdicts from five jurisdictions, which are similar to other available numbers. ${ }^{57}$ Medical malpractice awards are contrasted with three selected types of verdicts: products liability injuries, suits against governments, and automobile cases. The malpractice, products, and government cases all represent "deep-pocket" cases; automobile suits are expected to represent the lowest benchmark of common, "garden variety" personal injury. Figure 1 shows that simple averages of verdicts are indeed far higher for medical malpractice than for the three other types; malpractice verdicts were fully 6.5 times higher than automobile verdicts in 1980.58 Malpractice verdicts were even higher than the other two deep-pocket categories. Moreover, the gaps seem to be widening. As Figure 1 shows, the simple malpractice-automobile personal liability ratio rose to 11.1 to 1 in

55. See, for example, notes 8,63 and accompanying text.

56. See, for example, Daniels \& Andrews, The Shadow of the Law (cited in note 6).

57. For such previously published information, see, for example, Jury Verdicts Reports, Injury Valuation Reports, no. 314, Current Award Trends (Jury Verdict Res, 1989); these data are national in scope but not representative, see Russell Localio, Variations on \$962,258: The Misuse of Dala on Medical Malpractice, L Med \& Health Care 126 (June 1985).

58. This ratio is actually lower than the previously reported figures for two of the jurisdictions represented here. Michael G. Shanley \& Mark A. Peterson, Comparative Justice: Civil Jury Verdicts in San Francisco and Cook Counties, 1959-1980, at 32, 33 (RAND, 1983) (8.6:1 ratio of means in San Francisco, 1975-79); Mark A. Peterson, Compensation of Injuries: Civil Jury Verdicts in Cook County 31 (RAND, 1984) (8.2 ratio of medians). 
FIGURE 1

\section{Mean Jury Verdict by Case Type and Year}

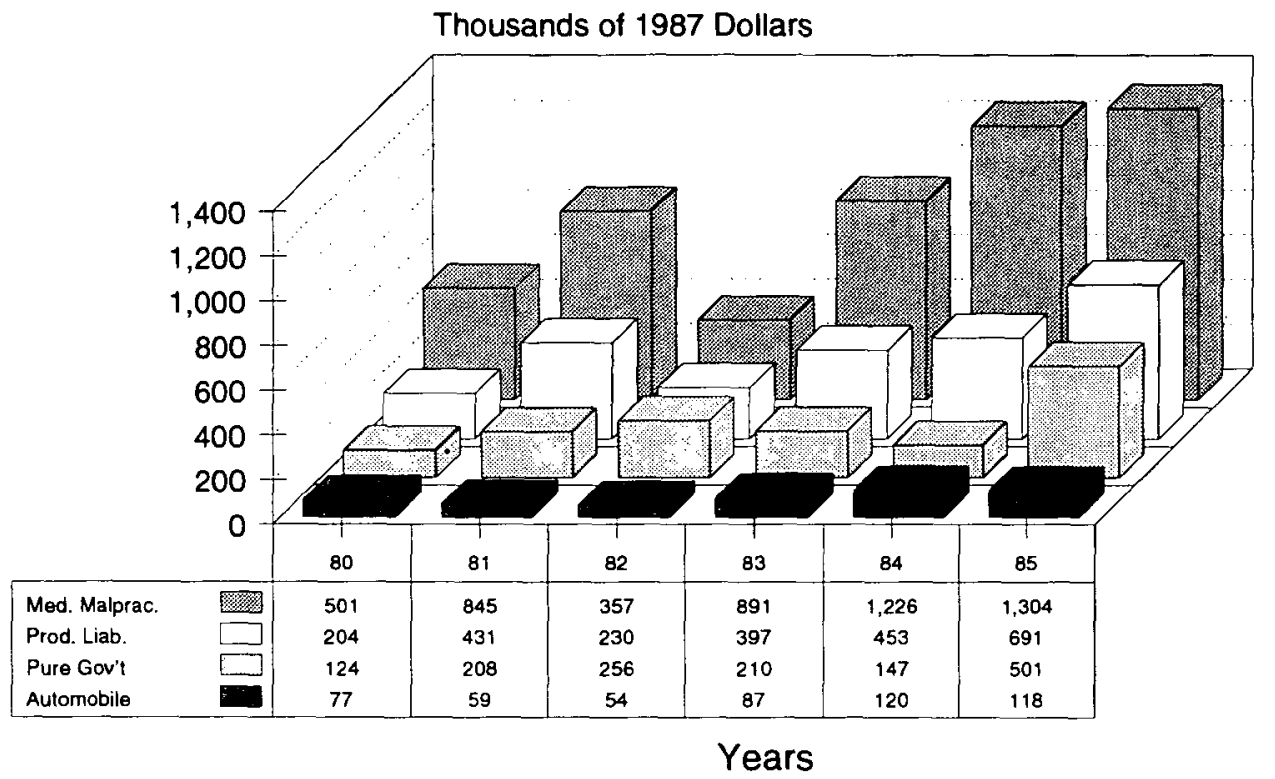

1985.59 Such gross disparities in jury outcomes are used to support physicians' current quest for even more drastic reforms of the liability system, ${ }^{60}$ even though liability insurance rates have recently declined. ${ }^{61}$

\section{B. Physicians' versus Lawyers' Explanations ${ }^{62}$}

Physicians (and their attorneys) typically see data like those in Figure 1 as proof of their feeling that the legal system is biased against them, and getting worse. They think that differentials occur because juries are unusually generous to patient-plaintiffs, at least in part because of insured doctors' and hospitals' "deep pockets" for paying awards. ${ }^{63}$ Because malpractice plaintiffs

59. Compare Mark A. Peterson, Civil Juries in the 1980s: Trends in Jury Trials and Verdicts in California and Çook County, Illinois 21 (RAND, 1987) (13.4:1 ratio of means for Chicago in 1980-84, 8.9:1 for California).

60. See Am Med Ass'n, A Proposed Alternative (cited in note 3).

61. See, for example, David Holthaus, Insurance Crisis Is Over-At Least for Now, Hospitals 46 (April 20, 1988).

62. This subsection presents an idealized version of competing hypotheses that is generally consistent with typical attitudes among these two professions. The authors are responsible for the precise statement of these positions.

63. See, for example, James Lewis Griffith, What It Will Take to Solve the Malpractice Crisis, Med Econ 193, 195 (September 27, 1982) ("Too often [jurors] act like Santa Claus, handing out millions of dollars in cases involving comparatively minor injuries."). Perhaps it should be noted that simple jury bias against "the rich" is not the only explanation that juries might treat deep-pocket defendants differently. It could be that institutional defendants are held to a different standard of care as well. Consider slips and falls, a common cause of action. Juries might well expect apartment buildings and businesses to shovel snow and clean up slippery spills more promptly than ordinary homeowners, for 
receive extravagant amounts in malpractice cases, their contingent-fee lawyers also earn too much-far more than needed to assure competent representation. Hence, the lawyers are willing to take even more and weaker cases to trial in the hopes of hitting the "jackpot." As a result, too many malpractice cases are non-meritorious or even "frivolous," this argument concludes.64 The doctors' position could thus be called the "generosity/demand pull" hypothesis, that is, that unduly high awards attract more cases.

Plaintiffs' attorneys can counter that there are other, valid reasons that malpractice awards tend to be higher. Malpractice claims are inherently more costly to bring and more difficult to win than, say, automobile cases. Malpractice cases face a higher legal standard for establishing negligence, which must be shown by expensive expert testimony, ${ }^{65}$ and involve complex sets of facts that call for more legal talent and investigatory resources. ${ }^{66}$ Higher costs on each case mean that lawyers need a higher gross award to earn the same net return; moreover, a lower win rate requires higher recoveries to cover their costs on the losers. Thus, lawyers must screen out less severe malpractice cases that would be litigable if they were automobile injuries. The failure to adjust Figure l's awards for other influences on their value thus explains the differentials. Moreover, medical plaintiffs' task has become even harder over time, given the increasing complexity of medical practice and the spread of tort reform, especially reforms aimed at malpractice. These developments have accordingly forced even greater selectivity of cases, which tends to explain the widening differential over time. This position might be termed the "selectivity/cost push" hypothesis.

In sum, the doctors assert that the high damages available to malpractice claimants engender cases with a low probability of success. The plaintiffs' lawyers see causation running the other way, that the lower likelihood of winning and higher costs of malpractice litigation leads to selection of higherdamage cases.

\section{Descriptive Data versus Controlled Analysis}

Figure 1 and similar displays cannot choose between these hypotheses. Both the doctors' charges and the lawyers' riposte seem logical on their face. Moreover, both the demand-pull and cost-push hypotheses can explain the simple picture of unadjusted differentials across types of cases, and are consistent with the apparent trend over time. But which is right, if either, about jury behavior? Does overgenerosity promote less meritorious cases?

example. Any such attitude should directly affect determinations of liability, however, not sizes of awards.

64. For example, Am Med Ass'n, A Proposed Alternative at 5 (cited in note 3) (remarks of Dr. Flaherty).

65. See generally Prosser E Keeton (cited in note 5); Edward Brunet, The Use and Misuse of Expert Testimony in Summary Judgment, 22 UC Davis L Rev 93 (1988).

66. Compare Special Committee on the Tort Liability System, Towards a Jurisprudence of Injury at 11-25 to 11-38 (cited in note 47 ). 
Or do difficulties proving malpractice force selective cutbacks on cases taken to trial?

The true picture can emerge only from controlled statistical analyses, to which the remainder of this article is devoted. To date, evidence on jury verdicts has largely been descriptive. RAND has stood virtually alone in conducting multivariate analysis on jury verdicts, contrasting different types of cases. ${ }^{67}$ This article provides advances on the RAND methods. Parts IV, V, and VI present our three sets of analyses.

The data used in this article, not only in Figure 1 but also in the more important analyses that follow, come from private jury verdict reporters in five jurisdictions: Chicago; San Francisco and other parts of California; the state of Florida; Kansas City, Kansas; and Kansas City, Missouri. For the first two jurisdictions, we benefitted from previously collected RAND data. Information from the latter three were compiled in the same format specifically for this article. These five areas are geographically disparate and otherwise representative of different types of areas across the country. ${ }^{68}$

\section{IV}

First Analysis: The Existence of Differential Jury Awards

This section begins this article's more detailed analysis of patterns and trends in jury verdicts, contrasting medical malpractice with comparison types of cases. It first revisits the seemingly straightforward question of whether malpractice verdicts are higher than others. Going beyond Part III, this section makes comparisons controlling for the severity of injury and other relevant factors. ${ }^{69}$

\section{A. How Type of Case and Other Variables Influence Verdict Size}

Regression analysis was used to examine what factors influence juries' decisions on liability and size of awards (the "dependent variables" in the regressions). Our major interest was the influence of case type, specifically, the four types already noted-malpractice, products liability, government, and automobile. ${ }^{70}$ The analysis controlled for severity of injury, jurisdiction, and other relevant factors, including economic loss, age, and extent of

67. See sources cited in note 8 above. For additional empirical analysis on the actual performance of juries, but lacking the same comparative focus, see also, for example, Daniels \& Andrews, The Shadow of the Law at 161 (cited in note 6).

68. Appendix 1 explains the data in greater detail.

69. This and subsequent investigation relies on multiple regression analysis. These statistical techniques examine the influence on an outcome of various measured factors, each considered as though the others were held constant. For an introduction to the use of multiple regression, see Daniel L. Rubinfeld \& Peter O. Steiner, Quantitative Methods in Antitrust Litigation, 46 L \& Contemp Probs 69, 88-104 (Autumn 1983).

70. We discuss only the "pure" case types in text. See Appendix 2 on "hybrid" cases. 
comparative negligence found by juries-all of which are "independent variables." A time-trend variable was also included. ${ }^{71}$

Table 1 presents the results from regression analyses for two dependent variables: The first, presented in column 1 , is the probability that the plaintiff wins an award. The second, in column 2 , is the size of the award, if there was one, expressed mathematically as the natural logarithm of the actual dollar amount. The coefficients presented show the relative influence of each variable on probability and size of awards. ${ }^{72}$ (Standard errors are given in parentheses, and levels of statistical significance are indicated.)

This section considers column 2's results on the size of awards. ${ }^{73}$ The influence of case type is shown by the regression coefficients for "auto," "product liability," and "government." Malpractice awards were the omitted category, the reference against which the other types are compared. The negative signs of the coefficients for the other case types show that their awards were all lower than for malpractice cases. From the values of the coefficients, we calculate that malpractice awards were about three times higher than awards in automobile cases, slightly more than products liability, and almost twice that of government cases. Only the automobile award coefficient was statistically different from medical malpractice (at the 1 percent level, which means that this result could be expected as a result of chance only 1 percent of the time).

In general, severity of injury also had a statistically significant impact, as one would expect. More severe injuries received higher awards; the relevant coefficients show a consistent pattern vis-a-vis award size. The least serious injuries (numbers 1 and 2 on the six-point scale) received lower awards than death cases (the omitted category). In contrast, the most severe injuries (numbers 4 and 5) received higher awards than death cases. The most severely injured living plaintiffs received awards that were about nine and a half times larger than awards received by the least severely injured plaintiffs. The separately calculated severity index also had a highly significant positive effect on awards. On the other hand, whether injury aggravated a preexisting condition or whether there was loss of consortium had no significant effects on awards.

Other variables generally had the expected impact. For example, reported medical expenses and wage loss had highly significant, positive coefficients: a 10 percent increase in medical expense, for example, led to about a 3 percent increase in awards (regardless of type); and a 10 percent rise in wage loss raised awards slightly less than 1 percent.

71. A full list of the variables used and a more detailed explanation of our approach appear in Appendix 2.

72. The relative sizes of awards cannot be read directly from the coefficients presented in Table 1. Instead, the "marginal effects" of each must be mathematically calculated according to a formula given in Appendix 2.

73. We also ran separate regressions that omitted the time trend. In these regressions, not reported here, the malpractice-automobile and malpractice-government differences were both highly significant ( $1 \%$ level), but malpractice and product liability awards were not significantly different. 
TABLE 1

Regression Results: Probabilities of Winning and Awards (ALl INJURIES)

\begin{tabular}{|c|c|c|c|c|}
\hline Explanatory Variables & Probability of $\mathrm{V}$ & inning* & $\log A v$ & rd** \\
\hline Intercept & -0.044 & $(0.16)$ & $5.59^{2}$ & $(0.55)$ \\
\hline Auto & $0.78^{2}$ & $(0.16)$ & $-0.94^{2}$ & $(0.26)$ \\
\hline Product liability & 0.44 & $(0.28)$ & -0.05 & $(0.43)$ \\
\hline Government & $0.60^{\mathrm{b}}$ & $(0.24)$ & -0.27 & $(0.37)$ \\
\hline Time & 0.006 & $(0.013)$ & 0.014 & $(0.022)$ \\
\hline Time auto & 0.007 & $(0.015)$ & -0.012 & $(0.024)$ \\
\hline Time product liability & -0.009 & $(0.026)$ & -0.011 & $(0.039)$ \\
\hline Time * government & -0.015 & $(0.023)$ & -0.034 & $(0.034)$ \\
\hline Hybrid government cases & 0.17 & $(0.25)$ & $-1.69^{2}$ & $(0.40)$ \\
\hline Hybrid cases with medical malpractice & $-0.92^{a}$ & $(0.27)$ & 0.36 & $(0.41)$ \\
\hline Hybrid cases without med. malpractice & 0.29 & $(0.17)$ & -0.34 & $(0.31)$ \\
\hline Time ${ }^{*}$ hybrid government & 0.033 & $(0.024)$ & $0.10^{2}$ & $(0.037)$ \\
\hline Time * hybrid with medical malpractice & $-0.061^{b}$ & $(0.026)$ & -0.062 & $(0.039)$ \\
\hline Time $*$ hybrid without med. malpractice & 0.014 & $(0.018)$ & 0.007 & $(0.029)$ \\
\hline Injury 1 & 0.059 & $(0.057)$ & $-1.07^{a}$ & $(0.22)$ \\
\hline Injury 2 & $0.18^{a}$ & $(0.053)$ & $-0.37^{c}$ & $(0.19)$ \\
\hline Injury 3 & $0.19^{2}$ & $(0.056)$ & 0.20 & $(0.18)$ \\
\hline Injury 4 & $0.28^{a}$ & $(0.074)$ & $0.94^{\mathrm{a}}$ & $(0.17)$ \\
\hline Injury 5 & $0.25^{b}$ & $(0.10)$ & $1.45^{\mathrm{a}}$ & $(0.18)$ \\
\hline Injury missing & $-0.86^{a}$ & $(0.13)$ & $-0.86^{\mathrm{a}}$ & $(0.32)$ \\
\hline Injury index & & & $0.35^{3}$ & $(0.041)$ \\
\hline Injury aggravated pre-exist condition & $0.16^{2}$ & $(0.045)$ & -0.09 & $(0.06)$ \\
\hline Original number of plaintiffs & -0.002 & $(0.015)$ & $-0.10^{2}$ & $(0.024)$ \\
\hline Original number of defendants & 0.064 & $(0.013)$ & $0.034^{c}$ & $(0.018)$ \\
\hline Medical expense & & & $0.34^{2}$ & $(0.018)$ \\
\hline Medical expense missing & & & $3.16^{\mathrm{a}}$ & $(0.17)$ \\
\hline Wage loss & & & $0.097^{2}$ & $(0.015)$ \\
\hline Wage loss missing & & & $0.81^{\mathrm{a}}$ & $(0.15)$ \\
\hline Newborn & & & $0.65^{b}$ & $(0.25)$ \\
\hline Age 1.10 & & & -0.023 & $(0.16)$ \\
\hline Age $11-17$ & & & 0.087 & $(0.14)$ \\
\hline Age 18-35 & & & 0.086 & $(0.094)$ \\
\hline Age $36-50$ & & & 0.083 & $(0.098)$ \\
\hline Age 51-64 & & & $0.20^{\mathrm{b}}$ & $(0.10)$ \\
\hline Age missing & & & $-0.20^{c}$ & $(0.11)$ \\
\hline Female & & & $-0.10^{b}$ & $(0.04)$ \\
\hline Sex missing & & & -0.14 & $(0.14)$ \\
\hline Nonwhite & & & $0.19^{r}$ & $(0.11)$ \\
\hline Race missing & & & $0.17^{2}$ & $(0.061)$ \\
\hline Separated & & & $-0.27^{2}$ & $(0.10)$ \\
\hline Married status missing & & & $-0.12^{b}$ & $(0.061)$ \\
\hline Not working & & & $-0.19^{a}$ & $(0.069)$ \\
\hline Employment missing & & & -0.057 & $(0.077)$ \\
\hline Non-professional job & & & -0.12 & $(0.076)$ \\
\hline Job missing & & & $-0.24^{2}$ & $(0.089)$ \\
\hline Comparative negligence & & & $0.57^{2}$ & $(0.078)$ \\
\hline$\%$ of negligence & & & $-0.027^{a}$ & $(0.002)$ \\
\hline$\%$ of negligence missing & & & $-1.32^{a}$ & $(0.42)$ \\
\hline Settle & & & $0.26^{\mathrm{a}}$ & $(0.08)$ \\
\hline Loss consortium & & & 0.09 & $(0.11)$ \\
\hline Federal court & 0.14 & $(0.092)$ & $0.48^{2}$ & $(0.14)$ \\
\hline Kansas City, Missouri & $-0.94^{\mathrm{a}}$ & $(0.084)$ & $-0.54^{\mathrm{a}}$ & $(0.15)$ \\
\hline Kansas City, Kansas & $-0.95^{\circ}$ & $(0.095)$ & $-0.49^{a}$ & $(0.18)$ \\
\hline California & $-0.75^{a}$ & $(0.056)$ & $-0.22^{\mathrm{b}}$ & $(0.09)$ \\
\hline Illinois & $-0.80^{a}$ & $(0.063)$ & $-0.51^{\circ}$ & $(0.12)$ \\
\hline Log likelihood & -5426.2 & & & \\
\hline$\overline{\mathbf{R}}^{2}$ & & & & \\
\hline Sample Size & 8,3 & & 4.5 & \\
\hline
\end{tabular}

Source: Florida-Kansas City jury verdict and RAND jury verdict data (1973-87); see Appendices 1 \& 2.

Notes: - Estimated by Probit Analysis ( $T$-statistics in parentheses after coefficients)

* Estimated by Ordinary Least Squares (T-statistics in parentheses after coefficients)

a. Significant at 0.01 critical level

b. Significant at 0.05 critical level

c. Significant at 0.10 critical level 
One surprise, however, is that awards are not found to rise over time (with other explanatory variables included). Methodologically, this conclusion follows from the lack of statistical significance for the "time-interaction terms" in Table 1. The time trend in our regressions was interacted with each case type (shown as "time* case type"; the variable "time" alone represents its interaction with malpractice).

\section{B. Explaining our Observations}

Awards rose during 1973-87 and 1980-85 (Figure 1). Various factors that affect awards also changed systematically over time. Controlling for these other factors, the difference in jury awards between medical malpractice and automobile cases is far less than was shown in Figure 1. Controlling for severity, wage loss, medical bills, and other legitimate influences reduced the apparent malpractice-automobile differential to "only" three to one. This analysis does not explain who is right about why some case types get higher awards than others; it merely documents that they do.

Moreover, we find no support for the doctors' hypothesis that the gap in favor of malpractice plaintiffs grew during this period (which is longer than the period reflected in Figure 1). Controlling for other determinants of awards, the case-type differential did not worsen over time, contrary to doctors' fears and the unadjusted data in Figure 1. So either juries in these jurisdictions are not becoming significantly more generous or tort reforms have tended to counteract the juries' innate generosity. The latter explanation is not appealing, as reforms have varied by state as well as by type of case during this period (most have been for malpractice only), yet no statistically significant time trends were found anywhere.

It is surprising that, even controlling for other factors, differences persisted over time in levels of recovery by case type. The puzzle: Suppose that juries are truly over-generous to malpractice plaintiffs, regardless of severity of injury and other factors. Then, legal effort spent on malpractice cases earns much more relative to effort spent on other types of cases (see Part II). Why, then, did lawyers not learn this and bring still more malpractice cases, as common sense and Part II's model would suggest? Available information indicates that many cases are not litigated, much less pursued to trial. ${ }^{74}$ How can malpractice cases consistently pay more if plaintiffs' lawyers are equalizing returns across case types? We turn next to the perplexing issue of lawyers' expected returns on different types of cases.

74. See Peterson, Consumers Knowledge and Dietz, Baird \& Berul, The Medical Malpractice Legal System, both in Dep't of Health, Educ. \& Welfare, Report of the Secretary's Commission on Medical Malpractice Appendix, 658 and 87, 97-100, respectively (cited, respectively, in notes 19, 20). 


\section{V \\ Second Analysis: Expected Values by Type of Case}

Regardless of the average size of awards, a prospective jury case only has positive value if it is expected to win. The expected value is the product of the likelihood of winning an award and the size of that award, net of costs incurred to win. (See also Part II above.) Part IV calculated the likely awards by case type. This section documents the probabilities of winning and calculates the resulting expected values. The key to the puzzling persistence of differential recoveries is understanding what value attaches to different types of case.

\section{A. The Probability of Winning: Lower for Malpractice}

The probability of winning a jury award varied considerably by case type (Table 1, column 1). Malpractice scored the lowest of all, as can be seen from the positive coefficients for all the other types of cases in column 1. (Recall that malpractice is the "omitted" case type in Table 1 , so that it does not appear directly, but the other values are all relative to malpractice.) These differences were observed among case types even controlling for plaintiff characteristics, severity of injury, and other factors that also affect likelihood of winning. (Again, Appendix 2 discusses the regression variables used.) The probability of winning a personal injury trial was highest for automobile cases, followed by government cases, product liability cases, and malpractice cases, in that order.

From the findings reported in Table 1, we calculated that the predicted probability of winning in malpractice trials was $0.33 .{ }^{75}$ Automobile, government, and products liability cases had probabilities of winning of $0.64,0.48$, and 0.44 , respectively. ${ }^{76}$ The automobile and government categories had significant coefficients, so there is statistical confidence that these categories are indeed more likely to win than is medical malpractice.

Other variables also affected the likelihood of winning. Being in the least severe injury category (number 1) had no significant effect, but, otherwise, the win probability rose fairly consistently with severity of injury, other factors held constant, including case type. In addition, an injury that aggravated a preexisting condition had a significantly higher probability of winning. ${ }^{77}$ All the jurisdictions shown in Table 1-the two Kansas Cities, California, and Chicago-had lower win probabilities than Florida. The coefficients are

75. This prediction is not the simple average of wins observed, but rather controls for variation in the other variables. Specifically, predicted values were calculated at the sample means of other variables. See also Appendix 2.

76. As for the awards regression, the coefficients presented in Table 1, column 1, do not directly yield win probabilities but rather must be mathematically transformed. See Appendix 2.

77. As for the awards regression, we also included time trend terms for each case type. We found some slight evidence of a rising trend in malpractice win probabilities (as captured by the time variable) and in automobile probabilities, accompanied by a falling trend in product liability and government cases. However, all of the time trend variables are of negligible magnitude, and are statistically insignificant. 
negative and statistically significant. (Florida was the omitted category, so does not directly appear in the table.) However, there were no appreciable differences in win probabilities across the other four jurisdictions, and the observed difference may simply reflect differences in data gathering in that state. ${ }^{78}$ We found no statistically significant effect of federal versus state court trials on the probability of plaintiffs winning.

What is one to make of these differences? Our prior expectation was for the 50-50 win ratios predicted by theory (see Part II) and previously reported for Chicago and California: ${ }^{79}$ The reasons that the win ratio is not 50-50 as predicted by the theory of settlement may lie in the theory's assumptions. For example, it is quite plausible that the two sides are not both risk neutral, as the standard model presumes. Conventional wisdom is that individual plaintiffs are risk averse, ${ }^{80}$ but a defendant may also be risk averse. ${ }^{81}$ Moreover, the two sides' stakes in the outcome may not be symmetrical; defendants but not plaintiffs may well fear "spillover" effects on their reputations of a well-publicized verdict, rather than a quiet settlement. Defendants not infrequently impose as a condition of settlement that plaintiffs not discuss the settlement; they may also petition courts to seal the records of a case.

Similarly, liability insurers, which strongly influence the conduct of investigation and defense, are also apt to fear large verdicts more than large, private settlements. As formal findings, especially if upheld on appeal, verdicts may have larger spillover effects on the value of other pending and future cases. The same logic suggests that manufacturers especially fear the loss of a precedent-setting case against a particular product, for that may prompt other plaintiffs to bring "copycat" product lawsuits in a way not possible for plaintiffs in other types of cases. These spillover effects would

78. This result could be due to underreporting of Florida cases; the two Florida reporters attempt to cover verdicts statewide, whereas the others are limited to individual metropolitan areas. See Appendix 1.

79. RAND had previously reported descriptive (uncontrolled) data showing roughly a 51-49 split between plaintiff and defense victories, unchanged over 1960-79, for all case types in Chicago. Malpractice and products liability, however, showed not only a lower win percentage ( 33 and 38 , respectively), but also an upward trend over time, on an uncontrolled basis. Mark A. Peterson \& George L. Priest, The Civil Jury: Trends in Trials and Verdicts, Cook County, Illinois, 1960-1979, 11-19 (RAND, 1982) (R-2881-ICJ). For San Francisco, the overall win percentage was higher, less stable, but generally rising, with malpractice and products liability again below average but rising over time Shanley \& Peterson, Comparative Justice at 23-26 (cited in note 58). The win rate apparently rose again in 1980-84 for malpractice and products liability in both cities, again in an uncontrolled analysis. Peterson, Civil Juries in the 1980s at 43 (cited in note 59). Our data on Chicago and California came from RAND. See Appendix 1. Our controlled analysis reported in text, in contrast, found no increase in winning percentage over 1973-87 in five jurisdictions.

80. In Viscusi's analysis of risk aversion in the context of product liability, the defendant firm is assumed to be risk neutral and the plaintiff risk averse. Viscusi, $17 \mathrm{~J}$ Legal Stud 101 (cited in note 27).

81. See generally Gary M. Fournier \& Thomas W. Zuehlke, Litigation and Settlement: An Empirical Approach, 71 Rev Econ \& Stat 189 (1989) and references contained therein. Fournier and Zuehlke's results suggest that defendants rather than plaintiffs are risk averse. Nor is it implausible that defense attorneys tend to be risk averse and plaintiffs risk seeking (consider the personalities that want hourly payment rather than a percentage of winnings), which could influence their professional valuations of a case on behalf of clients. 
also make defendants, particularly in malpractice and products liability cases, willing to spend more on defense, necessitating greater countervailing efforts from the plaintiffs' side, with corresponding higher legal costs. ${ }^{82}$ To the extent liability insurers are influential, it may be noted that they figure in all types of litigation. Their influence may be greater in malpractice and products liability cases because physician-sponsored insurers dominate the malpractice insurance market. Moreover, many hospitals and manufacturers are self-insured, as are many governments, thus combining the defendant and insurer perspectives.

Plaintiffs might also have motives going beyond simple monetary recovery if they seek vengeance or thorough investigation of perceived wrongdoing. ${ }^{83}$ Thus, for example, a patient or her family might be determined to "get even" with a doctor they dislike or "get to the bottom" of unknown events during an operation, despite legal-medical advice that they are unlikely to win. Although one would expect plaintiffs' lawyers to resist incurring the legal costs of low-probability cases, there may be reputational benefits to them beyond immediate returns if they win a large-dollar, "long-shot" case. As already noted, the two sides may also have asymmetric information (plaintiffs knowing more about their own injuries, defendants more about their own allegedly substandard behavior). Finally, where the law as applied to the facts of an individual case is uncertain, parties are more likely to differ in their valuations and hence seek a trial. Differences from the model's assumptions could thus help explain the variance from the model's expected 50-50 results. In any case, we find no evidence that whatever behavior has caused the lower winning percentage has intensified over time.

\section{B. The Expected Value of Verdicts: Higher for Malpractice}

Both the probability of winning and the likely amount of winnings affect decisions to proceed to trial. Specifically, they combine to yield the expected value of a case. How do these values vary by type of case, if at all? This subsection adopts the perspective of the lawyer (or law office) seeking to maximize returns on a multi-case portfolio of "investments" in contingent fee lawsuits. According to "portfolio" theory, net expected returns to plaintiffs' attorneys should be equal across case types (Part II above).

What do the data show? We cannot directly observe lawyers' net returns because data on plaintiffs' lawyers' earnings and expenses were not available. We can, however, estimate gross expected awards. To do so, we combined results on the probability of winning (Table 1 , column 1, above) with results on awards if won (Table 1 , column 2 , above). Table 2 shows expected awards, based on predicted win probabilities and predicted awards (conditional on a finding of liability). ${ }^{84}$ The values for automobile, product liability, and

82. See Rowe, $47 \mathrm{~L} \&$ Contemp Probs at 159 (cited in note 23).

83. See, for example, Frank A. Sloan \& Chee Ruey Hsieh, Variability in Medical Malpractice Payments: Is the Compensation System Fair?, 24 L \& Soc'y Rev 997 (1990).

84. These results were calculated at the total sample means. 
government cases are given in relative terms, with malpractice scaled to 1.00 . The second column, " $\mathrm{C}$," in each pair is more important. ${ }^{85}$

TABLE 2

Expected Awards at Verdict

\begin{tabular}{|c|c|c|c|c|c|c|}
\hline \multirow[b]{2}{*}{ Casetypes } & \multicolumn{2}{|c|}{$\begin{array}{l}\text { Relative } \\
\text { Size of } \\
\text { Award } \\
\end{array}$} & \multicolumn{2}{|c|}{$\begin{array}{c}\text { Relative } \\
\text { Probability } \\
\text { of } \\
\text { Plaintiffs } \\
\text { Winning } \\
\end{array}$} & \multicolumn{2}{|c|}{$\begin{array}{l}\text { Relative } \\
\text { Size of } \\
\text { Expected } \\
\text { Award }\end{array}$} \\
\hline & NC & $\mathbf{C}$ & NC & $\mathrm{C}$ & NC & $\mathrm{C}$ \\
\hline Auto liability & 0.08 & 0.34 & 1.74 & 1.94 & 0.14 & 0.66 \\
\hline Product liability & 0.57 & 0.86 & 1.26 & 1.33 & 0.72 & 1.14 \\
\hline Government & 0.17 & 0.54 & 1.28 & 1.45 & 0.22 & 0.78 \\
\hline Medical malpractice & 1.00 & 1.00 & 1.00 & 1.00 & 1.00 & 1.00 \\
\hline $\begin{array}{l}\text { Predicted probability of plaintiff winning in medical } \\
\text { malpractice cases }\end{array}$ & & & 0.35 & 0.33 & & \\
\hline
\end{tabular}

Key:

NC: Not full controlled-based on regression that includes only case type, jurisdiction, and time trend, but not other characteristics of case. Results in table calculated at mean of time trend.

C: Controlled-based on regression that includes characteristics above, severity of injury, and other characteristics of case. Results in table calculated at mean of time trend.

The differentials in expected awards are not large on average (see the far right column of Table 2). Product liability expected awards are 14 percent higher than for malpractice, but this difference is based on regression results that were not statistically significant. Government cases are intermediate between malpractice and automobile cases. Hence, broadly speaking, the expected values across these case types seem consistent with the lawyerportfolio theory, with one exception: The expected awards for automobile cases are only two thirds those for malpractice cases $(0.66$ as compared to $1.00)$; or, conversely, malpractice scores half again higher. This differential is substantially less than the threefold difference seen in awards (Part IV), but it remains puzzling. ${ }^{86}$ Can it be true that lawyers could consistently earn more

85. There are two columns of figures for each category in Table 2, labelled NC and C. Column $\mathrm{NC}$ presents relatively non-controlled values, controlled only for jurisdiction and time trend (from a regression not presented in this article), whereas column $\mathrm{C}$ reflects fully controlled regression results from Table 1. We refer mainly to column $\mathrm{C}$ in text.

86. It should be recognized that plaintiffs (and hence their lawyers) do not always collect the entire reported amount of jury verdicts, and there is reason to think that post-trial changes reduce the differential in net returns discussed in text. Post-trial reductions are not infrequent, with additions less common. See Michael G. Shanley \& Mark A. Peterson, Posttrial Adjustments to Jury Awards (RAND, 1987) (R-3511-ICJ). Changes may be achieved by the trial judge through additur, remittitur, or other means (the jury verdict reporters often report on such adjustments, and the data analyzed include these changes when reported). After trial, further changes remain possible, either by settlement of the parties pending an appeal or by order of an appellate court.

Shanley \& Peterson report survey data on the extent of reduction by size of jury award and type of case in Chicago and California. Changes are said to occur in $20 \%$ of all verdicts $(30 \%$ of plaintiff wins and $5 \%$ of defense wins), with $15 \%$ of the $20 \%$ being increases and $5 \%$ decreases. Id at 26-27. Changes are extensive when they occur, causing an average reduction in all personal injury cases of 
by shifting effort from automobile cases to malpractice ones? If so, then why do they not do so?

\section{Explaining Persistent Differences in Expected Values}

According to theory, only two phenomena could explain the long-term maintenance of such a differential: The first is barriers to entry that prevent new lawyers (automobile specialists and others) from litigating ever-highervalue cases until expected returns equalize. The second is higher litigation costs; net expected returns might equalize even though the gross values do not.

There appear to be few barriers to lawyers selecting cases as they see fit. Among attorneys, there is informal, de facto specialization, ${ }^{87}$ and higher knowledge or talent seems to command a wage premium in law, as in other labor markets. ${ }^{88}$ However, there is no formal or de jure system of certified specialization (quite unlike medicine) that might prevent a lawyer from changing the mix of legal practice to include more malpractice cases than automobile cases, for example. Legally, any lawyer is entitled to litigate any case. Flexibility in choosing portfolios of cases is even greater if one considers the deciding entity to be the law firm rather than its individual lawyers. Given informal specialization, in the short run it may be hard to begin to litigate specialized cases like malpractice or products liability. But in the long run, talented lawyers from other specialties can enter any field, given sufficient motivation to do so. Thus, although we lack hard data on the extent of entry and exit of lawyers from various types of personal injury practice, we find this explanation very implausible.

The second explanation is a differential in costs of litigating medical malpractice (and products liability) cases versus others. This hypothesis is far more plausible on its face. Complex, high-stakes litigation like malpractice involves technical issues regarding both the standard of care and causation; thus malpractice trials require considerable non-legal expertise. Hence they almost certainly require more hours of legal time to investigate and resolve, and therefore probably cost more per case than "garden variety" automobile cases where liability often turns on simple fact finding and common sense, and causation is obvious. ${ }^{89}$ Moreover, available statistics bolster the highercost hypothesis: Insurance company data show that malpractice cases cost

fully $20 \%$ (id at ix, 34-36), 33\% for medical malpractice (id at x, 42-44). Unfortunately, these survey results cannot be directly used to adjust our jury verdict data, even for California and Chicago, because their reported "post-trial" reductions include remittitur accounts for some (presumably large) share of them. Id at 6 . The study is unclear on how its survey findings relate to jury verdict data from reporters, which often report verdicts after remittitur or additur.

87. See, for example, Dietz, Baird \& Berul, The Medical Malpractice Legal System at $92-95$ (cited in note 20) (on lawyers known to be malpractice specialists).

88. High-stakes cases probably attract higher-priced legal talent and greater effort on both sides, thus raising costs, but presumably canceling each other out in terms of outcomes.

89. Lawyers and investigators of high-stakes cases also plausibly earn higher fees per hour, see note 90. Moreover, to the extent that malpractice and products liability defendants or their insurers spend more on one case because of spillover effects on other cases, plaintiffs must follow suit, see text accompanying notes 29, 62-66. 
about twice as much to defend as automobile injury cases, for example (Figure 2). More precisely, loss adjustment expense ("LAE") averages almost one quarter of total losses for malpractice, only 12 to 15 percent for automobile passenger liability. ${ }^{90}$ Figure 2 shows little change over time. ${ }^{91}$

There are no corresponding data on plaintiffs' costs for litigation, as lawyers are not a regulated industry and law firms are not publicly owned corporations. However, the insurer-defendants' expense ratio is a reasonable proxy for plaintiffs' overall litigation costs by case type as well. Any given legal action on one side typically engenders a response from the other side, perhaps most obviously where one side's filing requires a reaction or where both sides appear for a deposition sought by one of them. ${ }^{92}$ Indeed, plaintiffs' litigation expenses may well be systematically higher. ${ }^{93}$ Plaintiffs' legal costs also may be growing faster over time, for many tort reforms intentionally sought to raise plaintiffs' costs relative to defendants' costs. It has also been estimated that total legal hours (plaintiff and defense) spent on all litigated cases (not just those litigated to verdict) is lower for automobile cases than for all other torts. ${ }^{94}$ In all, there is good reason to conclude that malpractice costs are persistently higher than automobile litigation costs. ${ }^{95}$ This cost differential not only helps reconcile the apparent imbalance in expected values but also helps explain why lawyers may disproportionately

90. LAE consists of those costs known to be attributable to investigation, litigation, and settlement of claims, notably payments to independent lawyers and claims investigators hired by the insurer. LAE does not include insurers' more general operating expenses. The reported ratio is LAE divided by the sum of claims losses plus LAE. Note, however, that available data apply to all claims settlement alike, with no differentiation for cases going to verdict. Although cases going to verdict obviously cost more, the differential between more and less costly litigation seems unlikely to diminish at trial. If anything, it might increase, as higher priced experts often earn even more for trial appearances than for pre-trial work.

91. The 1980-85 malpractice LAE data assume a "W-shaped" curve (Figure 2). Over 1978-88, the " $W$ " is even more pronounced (1978 being the first year with data on physician mutual insurers, which dominate malpractice coverage; 1988 the latest year available). There was continuous decline from 1978-82, the mid-point "spike" in 1983 (Figure 2), and a continuing rise from 1984 through 1988, to fully $30.23 \%$. The automobile liability LAE percentage is less variable, both in Figure 2 and over the longer period of 1978-88 (starting at $14.90 \%$ and ending at $13.79 \%$ ).

92. Compare Kakalik \& Pace, Costs and Compensation at 98-116 (cited in note 1) (analyzing University of Wisconsin data for automobile versus all other cases; note that patterns of lawyer effort are similar between plaintiff and defendant; also, hours per case are lower for automobile cases).

93. Theory and evidence both support this supposition. The defense bar clearly does specialize, and defense attorneys have long-term relations with insurer-defendants, which presumably create continuing expertise and give some economies of scale operation. The best empirical estimate is that plaintiffs' legal fees and expenses claim $24 \%$ of total monetary cost for all tort litigation, versus $18 \%$ for the defense. Id at xi. Moreover, the hours spent by plaintiffs' attorneys on non-automobile torts are higher than for automobile. Id at 100-01

94. Id.

95. A note of caution: We do not know with certainty to what extent these higher costs are embedded in lawyers' time versus other expenses (from filing fees to expert witnesses), although we expect that most of the differential is in legal time, as experts' roles, however large, are far smaller than those of the attorneys who solicit and use their testimony. Kakalik and Pace present relevant data from the University of Wisconsin Civil Litigation Project. Kakalik \& Pace, Costs and Compensation at 111 (cited in note 1). For litigation terminated in 1978 in 12 jurisdictions, expenses were only 7 . $10 \%$ of legal fees plus expenses, varying by type of case and federal versus state courts. However, only 287 cases reported such data, well under half the 654 cases in their sample. Id. 
select larger malpractice cases-lawyers cannot as readily afford to bear higher costs in smaller injury cases. ${ }^{96}$

\section{Figure 2}

Malpractice versus Auto Costs of Litigation

Loss Adjustment Expenses (1980-85) as a Percentage of Total Losses

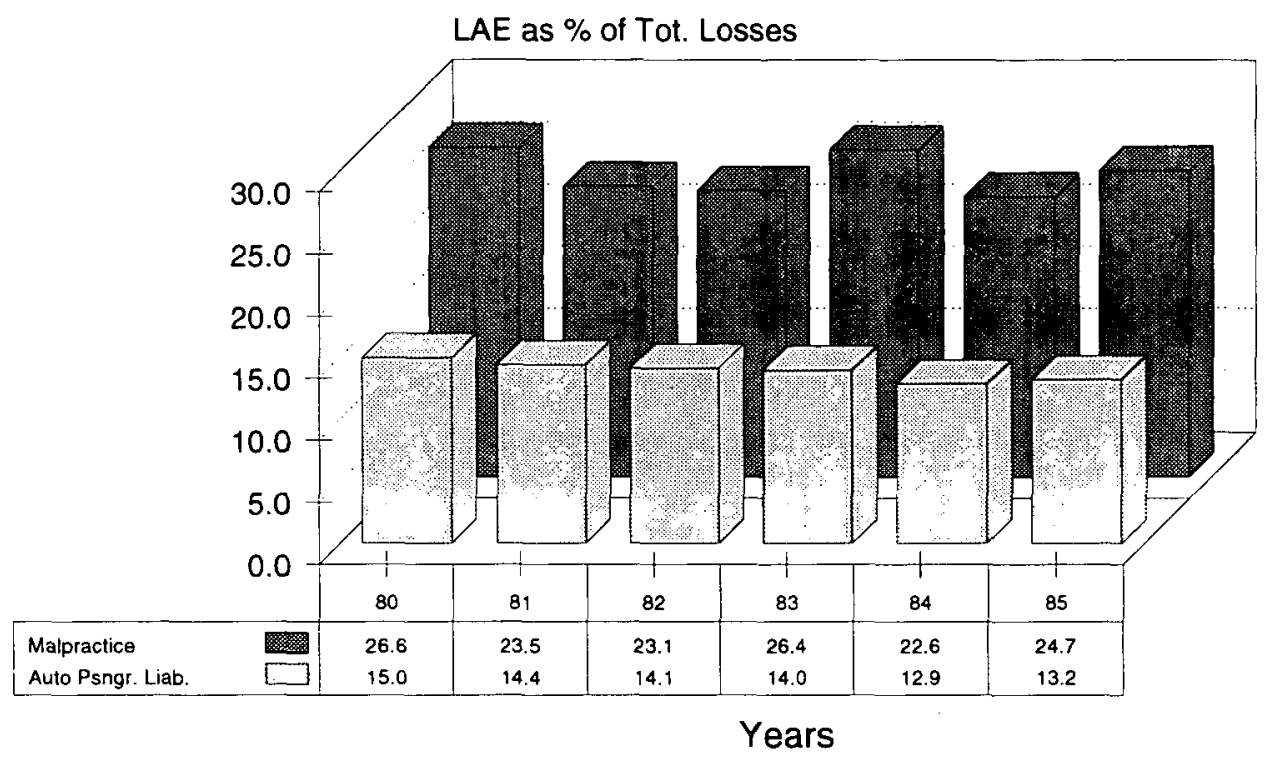

Source: Calculated from A. M. Best Company aggregate and averages, various years.

Just how much of the differential in expected value between malpractice and automobile cases might be explained by differences in cost? For purposes of illustration, consider that the average expected value of a malpractice case was about $\$ 300,000$ (in 1987 dollars), so that the expected value of an equivalent automobile case would be $\$ 198,000$ (0.66 as much), a difference of $\$ 102,000$. Some $\$ 51,000$, half of the difference in expected value, is explained by the cost differential of Figure 2.97

Thus, the large difference between malpractice and automobile awards is accounted for, in part, by malpractice's lower overall win rate and its higher

96. They could do so if contingency fees were higher for more complex cases, but it appears that a standard flat or sliding scale is applied across the board and not negotiated or adjusted case-bycase. Another adjusiment for higher non-attorney costs would be for plaintiffs to pay separately for expenses outside the contingent fee percentage; this does appear to happen, but apparently to a small extent. See note 95 .

97. The calculation: For malpractice, the 25\% LAE-to-total-loss ratio implies a cost-to-award percentage of $33 \%(0.25=0.33 / 1.33)$. For automobile, the $14 \%$ ratio implies a percentage of $16 \%$ $(0.14=0.16 / 1.16)$. The difference is $17 \%$ of the expected award; $17 \%$ of $\$ 300,000$ is $\$ 51,000$. This simplistic calculation assumes that LAE is a constant percentage across all stages of dispute resolution; more plausibly, expenditure rises as cases progress from initial claim through the legal process to trial. It also assumes that the LAE percentage is constant for all sizes of award; more plausibly, some costs are fixed, but others are variable in a non-linear relationship. 
costs. Thus, much of the differential in awards for the types of cases we examined can be explained from the plaintiffs' lawyers' perspective-either there are no excess returns to lawyers representing plaintiffs or the returns are not major. Thus, the puzzle about lawyers' behavior is to a large extent solved.

There remains a more important puzzle about juries' behavior, however, and hence about the accuracy and fairness of today's system of jury trials. Our analyses have not yet explained how juries are persuaded to pay more for a medical malpractice case than for a very similar case of automobile injury. After all, although juries plausibly understand that part of their award will go to compensate the plaintiff's attorney, no jury in any individual case knows anything about any of the patterns discussed here, most certainly not that malpractice costs are higher than others and the malpractice win rate lower.

\section{VI}

Third Set of Analyses: The Lawyers' Selection Hypothesis VERSUS THE DOCTORS' ThEORY OF OVER-GenEROUS

Juries, Continued

The foregoing two analyses controlled as well as possible for observable characteristics that legitimately affect jury verdicts across types of cases. Yet, despite adjustment for other influences, award differentials persist, with malpractice at the high end. It follows that some unobserved factor(s) must influence verdict size. This section considers the likely explanations. The two competing hypotheses are those first presented in Part III-the physicians' claim that juries are uniformly over-generous in malpractice cases and the plaintiffs' attorneys' response that malpractice trials feature only highly selective cases. This section considers the lawyers' view first.

\section{A. The Lawyers' Selection Hypothesis}

From the perspective of the plaintiffs' lawyers, one may contend that juries pay more for some types of cases because lawyers select cases with legitimately higher severity. Such differentials are by hypothesis ones that our objective severity measures do not capture (or the regression analyses would have controlled for them), so this also might be termed the "unobserved severity" hypothesis. After all, pain and suffering, disfigurement, humiliation, and other recognized non-pecuniary damages can legitimately vary according to idiosyncratic circumstances of an injury not described by its objective outcome on a six-point injury scale or an injury index.

On the other hand, some seemingly unobserved severity is not entirely missed by our variables: In particular, hard-to-quantify physical harm is partly captured by the variable for medical costs, as are those psychological harms treated with mental health services, and disfigurement treated by cosmetic surgery. Nonetheless, one can imagine that suffering, for example, could vary by case type, even where the objective severity category (like "major 
temporary injury") is the same. ${ }^{98}$ Thus, plaintiffs suing for delayed diagnosis of a painful disease might have more protracted non-pecuniary damages than for slow recovery from auto-accident trauma. We tested for "unobserved severity" in two ways, as discussed in the following subsections. ${ }^{99}$

1. Jury Verdicts in Cases Involving Death. First, we hypothesized that any unobserved differences in severity of injury would be least in the most severe, least ambiguous category-death. ${ }^{100}$ Controlling for factors like age, known pecuniary losses, and presence of consortium claim, deaths should be quite alike in unobserved severity, certainly more so than other severity categories. It is true that there are some differences-notably in the influence on nonpecuniary loss of the circumstances of death (for example, quick and painless versus lingering suffering). ${ }^{101}$ But differences in short-term circumstances should have least weight in the longest-term injuries. Therefore we analyzed death cases as a special example to test the hypothesis of unobserved severity.

We performed a pair of "death" regressions analogous to the all-injury regressions described above (Table 1). ${ }^{102}$ Contrary to the hypothesis, however, we found the same pattern of differential recovery by case type in death cases as in all-injury ones. If anything, the differentials were more extreme (although statistical confidence was lower because of the far smaller number of observations in this subset of the data). Because of this overall similarity, and to conserve space, death regressions are not presented.

2. Comparative Regressions across Case Types. Second, we ran regressions similar to the foregoing ones for each case type separately to examine the "structure" of juries' implicit "damages function." That is, we sought to tease

98. It may be objected that all injuries are idiosyncratic, and there really are no equivalents across cases, much less across case types. This argument proves too much. If taken literally, no disability program could function, and no epidemiological research would be possible. We know from research experience that the standard scale of injury severity can readily be applied in most cases, though there are boundary issues and some differences in "true" severity within a coded category. Perhaps the "loosest" category is "emotional only" injury, included in "severity l" in this article. It encompasses very minor, temporary discomfort or upset as well as long-term, severe mental illness or distress. But, as noted above, other variables, like medical expense, partly account for such differences. For another, more detailed attempt to scale severe injuries, see Frank A. Sloan \& Stephen S. van Wert, Cost and Compensation of Injuries in Medical Malpractice, 54 L \& Contemp Probs 131 (Winter 1991).

99. We also sought to test for a factor of "jury antipathy" by regressing payment on an index of culpability for automobile cases, plus the usual assortment of control variables. The index took account of such allegations as drunk driving and hit and run. However, results were inconclusivethe index's coefficient was not statistically significant when added to the automobile injury regression, and its addition did not change the $R^{2}$-and are not presented here.

100. Of course, different jurisdictions have very different rules on allowable damages in death cases, especially with regard to recoveries of non-pecuniary damages by survivors. See generally, Stuart M. Speiser, Recovery for Wrongful Death (Lawyer's Co-operative, 3d ed 1979); Prosser E' Keeton at 949-54 (cited in note 5); Dobbs, Handbook on the Law of Remedies at 557-62 (cited in note 42), but our analysis controls for jurisdiction.

101. The difference is legally consequential because conscious pain and suffering of a decedent is compensable.

102. The list of variables in the death regressions was identical to that in the all-injury regression (Appendix 2), except that severity of injury indicators were deleted, because death was the major symptom for these cases in that indicator. 
out what the relative importance was of various factors in contributing to the awards made and to compare these contributions by type of case.

Suppose the hypothesis is correct, and there was some unobserved severity in our data that systematically differed across case types (for example, larger actual pain and suffering for malpractice). This unknown factor would have changed the explanatory power of our known variables, reducing the overall amount of variation in results explainable by our measured factors. ${ }^{103}$ Hence, we expected to see differences across the case-type regressions in the separate coefficients of different explanatory variables, especially for severity of injury, as well as reduced explanatory power for all variables combined (a lower " $R$ "" statistic for the entire regression). ${ }^{104}$

We did not. To the contrary, what the results show is that the regressions are startlingly similar in coefficients and $\mathrm{R}^{2}$ (Table 3 ). ${ }^{105}$ The difference in the dollar value attached to malpractice and automobile injuries is almost wholly captured in the highly significant intercept terms of the regressions (with malpractice much higher than automobile). ${ }^{106}$

We conclude that juries probably value injuries in much the same way regardless of what type of case it is, except that, once liability is established, they more than double the amount for malpractice relative to automobile. In a sense, the same relative value scale seems to govern all cases (although different juries are involved); for example, with death values above temporary injury but below permanent major injury, different "multipliers" apply, that is, somehow, malpractice injuries are "worth" more than twice those that occur in automobiles.

The two analyses just described cast great doubt on the lawyers' hypothesis of selection based on unobserved severity. No doubt, attorneys (and clients) select which cases go forward to trial, rather than being settled or dropped without payment. But it does not appear that they do so on the basis of unobserved severity. Rather, we hypothesize the influence of an unobserved, multiplicative factor or factors, such as sympathy for the plaintiff. This possibility brings us back to the doctors' hypothesis.

\section{B. The Doctors' Sympathy, Antipathy, or Deep Pockets Theory}

The doctors hypothesize that they fare worse in objectively similar cases because of non-legitimate, subjective factors. That is, that juries are unduly generous because of some composite of juries' sympathy for injured patients,

103. 'In statistical jargon, it would have been a source of "standard omitted variable bias."

104. Omitting a variable results in biased coefficients for included variables that are correlated with the excluded variable. Moreover, if there were missing, unobserved variables that were more influential for malpractice than for automobile, then the $\mathrm{R}^{2}$ would be lower for the malpractice regression than for the automobile regression because the observed variables would account for less of the observed variation in awards. See G. S. Maddala, Econometrics 155-57 (J. Wylie, 1977).

105. T-statistics tended to be higher in the automobile regression, but this is a result of a larger sample size.

106. Results in the government and products cases were very similar. Again, to conserve space, they are not presented. 
TABLE 3

Regression Results on Awards by Case Type

\begin{tabular}{|c|c|c|c|c|}
\hline \multirow{2}{*}{$\begin{array}{l}\text { Explanatory Variables } \\
\text { Intercept }\end{array}$} & \multicolumn{2}{|c|}{ Auto Cases* } & \multicolumn{2}{|c|}{ Medical Malpractice* } \\
\hline & $4.04^{a}$ & $(0.11)$ & $8.64^{\mathrm{a}}$ & $(1.71)$ \\
\hline & 0.004 & $(0.011)$ & -0.003 & $(0.022)$ \\
\hline Injury level 1 & $-1.00^{\mathrm{a}}$ & $(0.32)$ & $-1.22^{c}$ & $(0.70)$ \\
\hline Injury level 2 & -0.43 & $(0.29)$ & -0.93 & $(0.58)$ \\
\hline Injury level 3 & -0.09 & (0.27) & -0.20 & $(0.53)$ \\
\hline Injury level 4 & $0.56^{\mathrm{c}}$ & $(0.30)$ & 0.55 & $(0.46)$ \\
\hline Injury level 5 & $1.34^{\mathrm{a}}$ & $(0.44)$ & $1.20^{\mathrm{a}}$ & $(0.37)$ \\
\hline Injury scale missing & -0.69 & $(0.42)$ & - & $(-)$ \\
\hline Injury index & $0.44^{\mathrm{a}}$ & $(0.06)$ & 0.15 & $(0.13)$ \\
\hline Injury aggravated pre-exist condition & -0.09 & $(0.08)$ & 0.007 & $(0.18)$ \\
\hline Original number of plaintiffs & $-0.10^{\mathrm{a}}$ & $(0.03)$ & -0.10 & $(0.10)$ \\
\hline Original number of defendants & $0.19^{2}$ & $(0.037)$ & 0.009 & $(0.040)$ \\
\hline Medical expense & $0.33^{\mathrm{a}}$ & $(0.02)$ & $0.26^{\mathrm{a}}$ & $(0.06)$ \\
\hline Medical expense missing & $3.22^{\mathrm{a}}$ & $(0.22)$ & $2.55^{\mathrm{a}}$ & $(0.59)$ \\
\hline Wage loss & $0.07^{\mathrm{a}}$ & $(0.02)$ & 0.10 & $(0.06)$ \\
\hline Wage loss missing & $0.52^{\mathrm{a}}$ & $(0.19)$ & 0.46 & $(0.71)$ \\
\hline Newborn & -0.95 & $(0.74)$ & $1.17^{\mathrm{a}}$ & $(0.44)$ \\
\hline Age $1-10$ & $-0.47^{b}$ & $(0.23)$ & 0.55 & $(0.45)$ \\
\hline Age $11-17$ & -0.18 & $(0.18)$ & 0.46 & $(0.41)$ \\
\hline Age $18-35$ & -0.08 & (0.13) & 0.34 & $(0.27)$ \\
\hline Age $36-50$ & -0.03 & $(0.14)$ & 0.14 & $(0.28)$ \\
\hline Age 51-64 & 0.02 & $(0.14)$ & 0.31 & $(0.29)$ \\
\hline Age missing & $-0.29^{c}$ & (0.15) & 0.21 & $(0.31)$ \\
\hline Female & -0.09 & $(0.06)$ & 0.10 & $(0.13)$ \\
\hline Sex missing & -0.18 & $(0.21)$ & -0.26 & $(0.32)$ \\
\hline Non-white & $0.37^{\mathrm{b}}$ & $(0.18)$ & -0.12 & $(0.27)$ \\
\hline Race Missing & $0.25^{\mathrm{a}}$ & $(0.08)$ & $0.44^{\mathrm{b}}$ & $(0.21)$ \\
\hline Separated (not married) & -0.22 & $(0.14)$ & $-0.50^{c}$ & $(0.30)$ \\
\hline Married status missing & -0.02 & $(0.08)$ & -0.05 & $(0.18)$ \\
\hline Non-professional job & -0.09 & $(0.10)$ & -0.38 & $(0.25)$ \\
\hline Job missing & $-0.26^{b}$ & $(0.12)$ & $-0.58^{b}$ & $(0.28)$ \\
\hline Not working & -0.08 & $(0.09)$ & 0.19 & $(0.19)$ \\
\hline Employment missing & 0.03 & $(0.10)$ & 0.33 & $(0.23)$ \\
\hline$\%$ of negligence & $-0.01^{\mathrm{a}}$ & $(0.001)$ & $-0.02^{\mathrm{a}}$ & $(0.004)$ \\
\hline$\%$ of negligence missing & $-1.21^{\mathrm{a}}$ & $(0.59)$ & 0.49 & $(1.30)$ \\
\hline Settle & $0.29^{b}$ & $(0.15)$ & 0.19 & $(0.21)$ \\
\hline Loss consortium & 0.14 & $(0.19)$ & 0.20 & $(0.23)$ \\
\hline Federal court & $0.84^{a}$ & $(0.31)$ & 0.21 & $(0.57)$ \\
\hline Kansas City, Missouri & $-0.87^{a}$ & $(0.25)$ & -0.29 & $(0.31)$ \\
\hline Kansas City, Kansas & $-0.65^{b}$ & $(0.27)$ & -0.07 & $(0.40)$ \\
\hline California & $-0.44^{\mathrm{a}}$ & $(0.15)$ & $-0.70^{\mathrm{a}}$ & $(0.19)$ \\
\hline Illinois & $-0.90^{\mathrm{a}}$ & $(0.17)$ & 0.23 & $(0.33)$ \\
\hline$\overline{\mathbf{R}}^{2}$ & 0.52 & & 0.51 & \\
\hline Sample Size & \multicolumn{2}{|c|}{2,393} & \multicolumn{2}{|c|}{426} \\
\hline
\end{tabular}

- Estimated by Ordinary least Squares (T-statistics in parentheses).

a. Significant at 0.01 critical level

b. Significant at 0.05 critical level

c. Significant at 0.10 critical level 
antipathy to well-heeled physicians, and the additional deep pocket of liability insurance. ${ }^{107}$ Thus, systematic bias makes malpractice cases "worth" more simply by virtue of being malpractice cases, regardless of other factors. This hypothesis is not without appeal. It is plausible that jurors would sympathize more with injured patients or consumers than with injured drivers: motorists seem to control their own destiny, whereas patients are given a surgical operation and consumers a finished product on a take-it-or-leave-it basis. ${ }^{108}$ Moreover, as already noted, even neutral observers have concluded that a defendant's deep pockets may affect awards, although jurors are in legal theory not informed about how deep different pockets are. To varying degrees, legal theory and common sense hold such motivations illegitimate. Compensation is supposed to be based on need for recompense, not emotional appeals.

The hypothesis is thus quite plausible, but what evidence supports the physicians' view? First, all three of our case types with deep pocket defendants did have higher awards. Second, the plaintiffs' lawyers' explanation of unobserved severity as the reason for award differentials is not persuasive, as just discussed; and the sympathy, antipathy, or deep pocket theory does better explain these results. Third, holding type of case constant, the win percentage generally rises with severity of nonfatal injury, which is consistent with sympathy for needy plaintiffs. Yet we know of no direct evidence of systematic sympathy, as opposed to occasional, anecdotal instances.

However, the theory that systematic sympathy (or other bias) depends merely on the nature of the defendant seems implausible. First, the hypothesized style of sympathy should apply across the board. Not only should it encourage juries to award higher damages but also to find liability more often to begin with (a non-zero award is needed to help the sympathetic plaintiff or punish the defendant) ${ }^{109}$ Yet, the plaintiffs' winning percentage is, on its face, unsympathetically lower for malpractice and products liability

107. Other subjective influences might also be hypothesized, but these three seem to be the main ones.

108. One might note, further, that because nearly everyone has himself at some point made a mistake behind the wheel, jurors plausibly also empathize more with defendant drivers than with defendant doctors. Antipathy could also arise in the high-award types of cases because of the failure of the pre-existing relationship of such plaintiffs and defendants. An underappreciated psychological truth is that a failed relationship or lapse of trust engenders the harshest feelings, as divorce lawyers can verify. Such antipathy could make such plaintiffs more likely to hold out for trial and possible vindication-even if the chance of success is low-and juries could share it in awarding damages. Malpractice cases are the strongest example of this hypothesized form of antipathy, for trust is the essence of the doctor-patient relationship. To a lesser degree, consumers also buy safety in reliance on manufacturers' products, and have an ongoing relationship with their governments, albeit sometimes one with low expectations. In contrast, drivers' previous relationships with other drivers is transitory and often competitive.

109. Compare Jeffrey W. Jacobson, Medical Malpractice and the Tort System, $263 \mathrm{~J}$ Am Med Ass'n 3320,3324 (April 25, 1990) (speculative to blame juries for being more generous than legal rules in malpractice cases where defendants win most cases). Across-the-board sympathy should also affect the value of all malpractice injuries, regardless of the stage of resolution, a hypothesis untestable by our data. 
cases than for automobile cases (Table 2). ${ }^{110}$ From the doctors' perspective, one can assert that the observed win rate is low because lawyers bring very weak cases to trial, given that it is so easy to win normal cases. However, this reasoning is tortured and there is no corroborating evidence that this is so. ${ }^{111}$ There are also other reasons to believe that most malpractice cases (for example) are not particularly weak and juries are not biased in favor of finding liability: (1) a thorough review of malpractice litigation in one state found no evidence of such bias; ${ }^{12}$ (2) at least three reviews of malpractice insurance claims show that legal results relate to medical judgments about the quality of care given and the avoidability of the injury that occurred;113 and (3) if malpractice (and products) injuries were so easy to win, one would not expect to see such a low proportion of medical injury brought to litigation-certainly relative to automobile torts-nor so many potential malpractice claims rejected by lawyers. ${ }^{114}$

Second, if plaintiffs could automatically collect double on all winning malpractice cases, one would expect a less skewed distribution of jury awards. Malpractice cases (for example) are skewed toward high-severity, high award cases; if it were easy to win, one would expect more small cases to go to trial. High litigation costs, with a large fixed-cost component, could prevent this. But the latter raises a third point: if it were easier to persuade juries of malpractice liability, one would expect litigation costs to be lower rather than higher. Fourth, although the finding that severity of injury relates to probability of winning superficially suggests an influence of sympathy, the severity influence seems to be independent of case type, not related to it.

Finally, there are simpler explanations available: the law of malpractice and products liability is indeed more favorable to defendants, which should make it harder to win such cases. Perhaps lawyers' negotiations in settlement should still make the win ratio 50:50, but there are reasons to expect deviation from this theoretical prediction. On balance, the hypothesis of across-the-

110. See also sources cited in notes 58-59 above.

111. This study cannot objectively determine meritoriousness because we have no way to measure the validity of a case independent of its jury's ruling on liability. In general, doctors probably overemphasize the errors made by the legal system on liability. See Jacobson, $263 \mathrm{~J}$ Am Med Ass'n 3320 (cited in 109); note 113 and accompanying text.

112. See Metzloff, $54 \mathrm{~L} \&$ Contemp Probs at 82-84 (cited in note 25).

113. See Thomas M. Julian, et al, Investigation of Obstetric Malpractice Closed Claims: Profile of Event, 2 Am J Perinatology 320 (1985); Randall R. Bovbjerg, Laurence J. Tancredi \& Daniel S. Gaylin, Obstetrics and Malpractice: Evidence on the Performance of a Selective No-Fault System, $265 \mathrm{~J}$ Am Med Ass'n 2835 (June 5,1991 ) (liability payment twice as likely for malpractice claims on list predefined as medically avoidable as for claims not on list); Sloan \& Hoerger, J Risk \& Uncertainty (cited in note 49).

114. See Danzon, Medical Malpractice at 20-25 (cited in note 15) (ratio of malpractice claims to hospital injuries in high-claims state of California between 1:10 and 1:5); All-Industry Research Advisory Council, Attorney Involvement at 9-11 (cited in note 19) (lower percentage of families see lawyers after medical than automobile accidents). See also Dietz, Baird \& Berul, The Medical Malpractice Legal System at 97-100 (cited in note 20) (rejections by attorneys); Sloan \& Hsieh, 24 L \& Soc'y Rev at Table 2 (cited in note 83 ) (malpractice claimants received payment in $80 \%$ of cases presuit, $43 \%$ after suit and before verdict, but only in $22 \%$ of cases decided at verdict; vast majority settled at the pre-verdict stage). 
board sympathy for patient plaintiffs and antipathy to doctors and other deep pockets is not persuasive.

\section{A Combined Interpretation: Sympathy-Based Selection}

We conclude that the plaintiffs' lawyers are right to emphasize selection but the doctors are right that sympathy and other subjective factors are a basis for selection. We hypothesize that all "pools" of injuries-from malpractice, automobile accidents, and other causes-contain cases of varying degrees of sympathy. Selection occurs across all case types at every stage of the legal process, but necessarily plays a larger role where liability is intrinsically harder to prove and where trial entails especially high costs, as for malpractice. That is, not every malpractice injury is inherently more sympathetic (nor every doctor more antipathetic), but malpractice cases going to litigation and ultimately to trial are selected to feature such subjective factors, ${ }^{115}$ ones not captured by our quantitative methods.

What (unobserved) characteristics drive this selection process? Sympathy and antipathy indeed seem very plausible factors. So does severity of injury, for two forms of which our analyses have controlled. The deep-pocket explanation seems more plausible as a matter of attorneys' selection (based on the extent of insurance coverage or attachable assets discovered in preparation for trial) than as an explanation of jury response to the circumstances of a case. Selection makes sense, for plaintiffs' lawyers are very unlikely to incur the expense of trial if probable damages exceed the depth of the defendants' pockets, including insurance. So all trials are likely to involve "deep enough" pockets. ${ }^{116}$

Jury bias based on deep pockets makes less sense: First, the straightforward depth-of-pocket model does not explain the relative ranking of automobile, government, products liability, and malpractice cases. The latter three indeed have deep pockets, but the very deepest would seem to be large defendants in products liability cases, followed by government, and only then by insured hospitals or doctors. This is not the order indicated by the observed awards, however, in either raw data (Figure 1) or adjusted for other factors (Table 1). Moreover, within the malpractice category, doctors bear a much higher liability burden than hospitals, as measured by insurance

115. Plausibly, people injured by doctors have a harder time recognizing that their injury results from substandard care rather than from their underlying condition, and they face more of an uphill battle to show liability. Hence, the process disproportionately selects the more vengeful-and monetarily needy-plaintiffs right from the start. Plaintiffs' lawyers' expert counsel again weed out cases before bringing lawsuits and further select for trial cases known to be likely to win big awards within each category of injury severity.

116. It is a stylized fact that virtually all doctors and hospitals are insured, with liability limits routinely in the millions of dollars, US Gov't Acct'g Office, Medical Malpractice: Insurance Costs Increased by Varied Among Physicians and Hospitals (September 1986) (GAO/HRD-86-112), whereas drivers are often uninsured or covered for low levels. Statutorily required automobile coverage may be as low as $\$ 10,000$ per injury (in six states); the highest required is $\$ 50,000$ (one state). Insurance Information Institute, Insurance Facts: 1986-87, Property/Casualty Fact Book 104 (1986). However, no lawyer with a quadriplegic client seems likely to go to trial against an insurance attorney obligated to pay a maximum of $\$ 10,000$ or even $\$ 50,000$. 
premiums, whereas hospital enterprises clearly have deeper pockets, especially beyond the limits of purchased insurance coverage. ${ }^{117}$ Doctors pay more because they are, rightly, perceived to be the primary medical decisionmakers. Second, juries are apt to expect that ample insurance (or company or government self-insurance) will pay in all personal injury cases, thus equalizing the perceived depth of pocket. Plaintiffs' lawyers are quite talented in somehow conveying the fact of insurance to the jurors in the courtroom, despite its inadmissibility as formal evidence. Moreover, in this media age, it seems highly likely that at least one or two jurors will know enough to educate fellow jurors, regardless of events in the courtroom. For these reasons, we would downplay deep pockets as an explanatory factor in jury behavior.

In addition to sympathy and antipathy, there may be another important type of idiosyncratic, jury-affecting factor-namely, the relative litigation quality of the two parties (for example, how good an impression on a jury plaintiff and defendant are expected to make as witnesses) and their legal teams. As with sympathy, this is an unobserved characteristic.

Finally, we note that a better investigation of the interactions of selection and sympathy must await further study. What is needed is either a broader statistical study that can analyze both settlements and verdicts across case types, an analysis of the relative merits of actual verdicts with regard to liability and damages, or controlled experiments in jury decisionmaking, or some combination of these approaches.

\section{VII}

\section{Conclusion and Policy Implications}

This study analyzed the differences in personal injury awards between automobile and "deep-pocket" defendants, especially in medical malpractice cases. Six conclusions are particularly relevant to the legal policy debate: First, we found large and statistically significant differentials in jury awards for personal injuries between automobile cases (lowest) and medical malpractice (highest), even after adjusting for characteristics known to influence verdicts. Adjusted malpractice awards are almost three times larger than automobile awards. It is important to understand what causes these striking differentials in order to know whether they are a problem that merits attention through tort reform or otherwise.

Second, the observed differences in awards were not shown to grow over time, after controlling for other factors. Thus, award differentials seem to

117. For example, Randall R. Bovbjerg, Medical Malpractice on Trial: Quality of Care Is the Important Standard, 49 L \& Contemp Probs 321 , 322 (Spring 1986) (For 1984, physicians bore about two thirds of total cost for malpractice coverage.). Moreover, prior analysis of Florida malpractice insurance claims and of Florida and Kansas City jury verdicts found that payments were lower, not higher, when a hospital was listed as a defendant than when no hospital was listed. Sloan \& Hsieh, 24 L \& Soc'y Rev at 1021 (cited in note 83 ). With regard to probability of winning any payment, the latter analysis found that the win rate was lower for Florida malpractice claims with hospital defendants, but higher for Kansas City and Florida jury verdicts. 
have been no more and no less justification for malpractice-specific tort reforms in the 1980s (when many reforms were generic) than in the 1970s (when malpractice-only reforms predominated). ${ }^{18}$

Third, despite the larger verdicts in malpractice cases (for example), attorneys representing injured patients do not seem to be earning excessive compensation, "quasi-rents" in economic terminology. At least, the net value of malpractice cases does not seem out of line: the plaintiffs' win rate in malpractice is lower than in any of the other three types of cases examined, only half as high as for automobile; and legal costs appear to be higher for malpractice litigation than for automobile cases, more than twice automobile cases. Thus the net expected value of these cases seems to be roughly the same. This finding supports the theoretical expectation that lawyers equalize returns across case types and greatly undercuts the rationale for fee limits that do not recognize cost differentials (as most statutes do not) or that apply only to malpractice cases (as most statutes do). ${ }^{119}$

The lower win rate in malpractice could suggest that too many lessmeritorious cases go to trial, as doctors would argue, or instead that malpractice is intrinsically more difficult to prove and more vigorously defended by doctors, as plaintiffs' lawyers would contend. We cannot directly analyze these competing hypotheses using available data, although there are indications that legal determinations are in reasonable accord with medical standards in malpractice cases. The economic model of dispute resolution suggests that possible reasons for the lower win rate include differential risk aversion as between the parties and various asymmetries in the parties' expected gains and losses from trial.

Fourth, we reject one superficially plausible hypothesis about why juries decide to pay more for malpractice-that is, the plaintiffs' attorneys' argument that they select cases for trial that have suffered legitimately more severe injuries, just in ways not observable by analysis, for example, more severe pain and suffering. The law instructs juries to award more in such cases, and if the selection-by-unobserved-severity hypothesis were verified, no reform would be needed to address the differentials. In fact, however, two additional types of regressions (using death cases only and stratification of the sample by case type) failed to find support for this hypothesis, and we are reasonably confident in rejecting it.

Fifth, the remaining explanation for the differentials is that juries sometimes respond emotionally, awarding some objectively similar cases higher damages than others. Hypothesized factors include sympathy for certain plaintiffs, antipathy for certain defendants, higher quality legal cases in some instances, and, possibly, knowledge that certain defendants (or their insurers) have "deep pockets" and so can afford high awards. We suggest that some cross-cutting factor like sympathy must be influencing some

118. See Bovbjerg, 22 UC Davis L Rev at 543-44 (cited in note 11).

119. Id at 522-23, 544 . 
awards. Sympathy can have a large influence because the law gives so much leeway to juries to go beyond "legitimate" (and observable) factors in their decisionmaking: Juries can find for or against any plaintiff, with virtually any amount of damages, with little or no explanation; the rules of damages are very vague; and legal process gives reviewing judges no formal way to assure consistency of results in similar cases. That sympathy (and similar factors) plays some role is only common sense; just what role it plays is more problematic.

Sixth, there is no direct evidence on just how sympathy (or other similar factors) affects awards-either from this study or, to our knowledge, from elsewhere. The physicians' perspective is that sympathy (and other such factors) operates by case type, that is, that juries are intrinsically biased in malpractice cases, which therefore receive higher awards across the board for cases of objectively similar merit. This across-the-board sympathy should also raise plaintiffs' win percentage, other things equal; it does not, according to this theory, only because attorneys proceed with so many less meritorious cases. If verified, the across-the-board sympathy hypothesis would justify malpractice-specific reforms. Although the hypothesis cannot be entirely ruled out, it seems an oversimplification. For example, our regression showed that probability of plaintiffs winning rose with higher observed severity of injury. This finding is consistent with a sympathy effect, but one that operates independently of case type, for which the analysis controlled. It is also consistent with greater investment by plaintiffs' attorneys in highseverity cases, or with more talented plaintiffs' attorneys specializing in highseverity cases. ${ }^{120}$ If the hypothesis is not correct, then malpractice-specific reform needs to be justified on other grounds, such as errors in findings of liability or the very high costs of malpractice litigation.

In place of the lawyers' hypothesis of severity-based selection (which we reject) and the doctors' hypothesis of across-the-board sympathy (which we find unpersuasive), we suggest instead a combination of the two-sympathybased selection. That is, lawyers choose cases for trial according to their expert judgment on how juries will respond to various idiosyncrasies of a case, including relative ability to generate sympathy. The entire injury pool for each type of case is hypothesized to contain cases that vary from extremely sympathetic to very unsympathetic, and along other such dimensions as well. From the pool, relatively few unsympathetic cases go forward for malpractice, because the likelihood of losing and the cost of litigation are both too high. The same kinds of high sympathy cases occur and are litigated among automobile injuries, but high-sympathy cases are more predominant in highstakes litigation. Conversely, plaintiffs' lawyers have rejected less sympathetic malpractice cases, which for automobile injuries they might have taken to a jury, because these lower-value cases cannot pay their own way where liability is hard to establish and expensive to litigate.

120. See generally Frank A. Sloan, et al, Winners and Losers: How Medical Malpractice Claims are Resolved (submitted for publication March 1991). 
This combined hypothesis is certainly plausible and explains many observed phenomena, although direct verification is desirable. If correct, it implies that reforms of damages should address not merely malpractice, products liability, or government cases in isolation but rather the entire legal approach to ad hoc jury decisionmaking on damages. ${ }^{121}$ Reforms should make legal rules of damages less vague and more objective, especially with regard to non-pecuniary damages, giving juries better ways for making individual valuations and judges better ways for maintaining consistency across cases. Then, any biases would be less consequential and jury outcomes would be more predictable for all types of cases, facilitating settlement and making litigation less expensive. 


\section{APPENDIX 1}

\section{Data Base Development}

The data used in this study come from numerous jury verdict reporters within five separate jurisdictions: Florida; Kansas City, Missouri; Kansas City, Kansas; San Francisco and several other counties in California; and Cook County, Illinois. Jury verdict reporters are private publications that periodically publish summaries of numerous jury verdicts known to the editor, in a somewhat standardized format. ${ }^{1}$ The reporters used are believed to be unbiased by selection factors, although the two statewide Florida reporters clearly contain a lower proportion of all verdicts than do the other reporters, which cover metropolitan areas. The Florida and Kansas City data, for 197387 , were newly collected by this study. Data for the remaining jurisdictions, which were provided by RAND, cover only 1980-85; other years were not available at the time of analysis. The data collection instruments and instructions used for Florida and Kansas City were updated versions of the RAND forms, and RAND staff helped train the coders used, so the two parts of the data base are consistent.

Four major categories of personal injury cases were considered. These were automobile accidents (including all motor vehicles), medical malpractice, product liability, and personal injury cases involving government defendants (such as slips and falls on public property). The categories were chosen to illuminate the "deep pocket" theory of liability and award differentials. Information was obtained on liability and damages, plaintiff characteristics, and, to a lesser extent, defendant characteristics. ${ }^{2}$ Award amounts cover only jury verdicts, together with prior settlements by defendants previously dropped; cases with only settlements are not included. The trial judge's change in the verdict through additur or remittitur (if any) is normally shown, but not any change after verdict as a result of settlement or appeal. There is evidence that a substantial minority of malpractice verdicts are reduced after verdict, especially for very large verdicts. ${ }^{3}$

Nationally, the most common type of personal liability case is motor vehicle accidents. This is also reflected in the available sample. Of 8,388 observations on plaintiffs, 3,778 were in "pure" automobile cases (that case type only), followed by pure malpractice (1,130 cases), pure government (599), and pure product liability (348). The remaining cases were various "hybrids," each being a combination of two or more case types (for example, an automobile accident with a government driver, malpractice in a public hospital, or a medical injury claim against a doctor and drug company).

It is worth noting that for about a quarter of the observations medical expenses were not recorded, and for about half wages were not recorded. To preserve the sample size while maintaining the information content of these variables, binary variables were used for missing data, that is, an either/or indication was used rather than a numerical value. The same procedure was used for other variables.

1. For a description, see Mark A. Peterson, Compensation of Injuries: Civil Jury Verdicts in Cook County Appendix A, 59-67 (RAND, 1984).

2. For a longer description, see id at Appendix B, 68-86

3. See note 86 in main text. 


\section{APPENDIX 2}

\section{Regression Analyses}

In the log-award regression (Table 1 , column two), which was estimated by ordinary-least-squares, the dependent variable is the log of payments awarded by juries in all cases won. The main independent variable of interest was case type. Three types of personal injury cases are shown: automobile, product liability, and government (with medical malpractice the omitted category). We were mainly interested in the experience of these "pure" case types, and textual discussion focuses on them. Of course, a smaller number of combined case types also existed, for example, where a malpractice case was brought against a government hospital. These "hybrid" cases are difficult to interpret in isolation but help act as controls.

We used a six-point severity index, from minor injury (injury number 1) to death (omitted category) at the top of the scale created by RAND. We also created a composite injury index ("severity"), expressed as a monetary value, based on the plaintiff's symptoms, and we coded an indication of whether the injury seemed to aggravate a pre-existing condition.

There are five jurisdictions: Kansas City, Missouri; Kansas City, Kansas; California (several counties); Illinois (Chicago only); and the state of Florida (the omitted category).

Two measures of economic loss are included, the log of medical expense and the $\log$ of wage loss, each as given in the jury verdict reporter for its jurisdiction (data were sometimes missing). There are dummy variables for six age groups, newborn to age 51-64 (the elderly are the omitted category). Other plaintiff characteristics include sex (female versus omitted category of male); race and ethnicity (non-white versus white); marital status (separated and married status missing as well as unmarried versus married); and employment status. Other variables relate to the legal posture of the case, including original number of plaintiffs, original number of defendants, presence of comparative negligence, extent of negligence (expressed as a percentage), presence of derivative claims like loss of consortium, settlement (settlement before jury verdict by a previously joined defendant), and type of court (federal versus state).

In semilogarithmic regressions, the percent effects $(e)$ of dummy variables are given by $\ell=100\{\exp (d)-1\}$, where $d$ is the coefficient of the relevant dummy variable. Percent effects of all dummy variables reported in this article are based on this transformation. ${ }^{1}$

In the "probability of plaintiff win" analysis, we regressed the probability of winning, that is, a finding of liability in favor of the plaintiff, against several variables. As with the log award regression, we focus on the influence of "pure" case types, omitting discussion of the hybrid cases. The independent variables used are very similar to those in the log awards regression (Table 1). But some variables were omitted: medical expense, wage loss, age, sex and

1. See Robert Halvorsen \& Raymond Palmquist, The Interpretation of Dummy Variables in Semilogarithmic Equations, 70 Am Econ Rev 474 (1980). 
other plaintiff characteristics are used as proxies for the plaintiff's loss, which in legal theory should not affect the probability of winning, so they were excluded from the probability regression. We did incorporate severity of injury in this regression because some prior analyses suggest that it may be more difficult to find negligence in cases of low severity. ${ }^{2}$ The injury index, on the other hand, is not included because the injury scale is a sufficient proxy for this potential effect.

The probability regression was estimated by maximum likelihood probit. Marginal effects in the probit model used are obtained from a transformation of the regression coefficient. For continuous variables, the probit marginal effects are given by $\partial P / \partial X_{i}=f\left(b^{\prime} X\right) b_{i}$, where $b$ is the vector of regression coefficients, $X$ is the vector of explanatory variables, $X_{\mathrm{i}}$ is the continuous variable in question, $b_{i}$ is its corresponding coefficient, and $f$ is the normal density function. ${ }^{3}$ For dummy variables, marginal effects are obtained from the difference between the predicted probability at $d=1$, with the predicted probability corresponding to the omitted category (calculated at the sample means).

2. Patricia M. Danzon, The Disposition of Medical Malpractice Claims 50-51 (RAND, 1980); Patricia M. Danzon \& Lee A. Lillard, Settlement Out of Court: The Disposition of Medical Malpractice Claims, $12 \mathrm{~J}$ Legal Stud 361-62 (1982).

3. See G. S. Maddala, Limited Dependent and Qualitative Variables in Econometrics 21 (Cambridge U Press, 1983). 